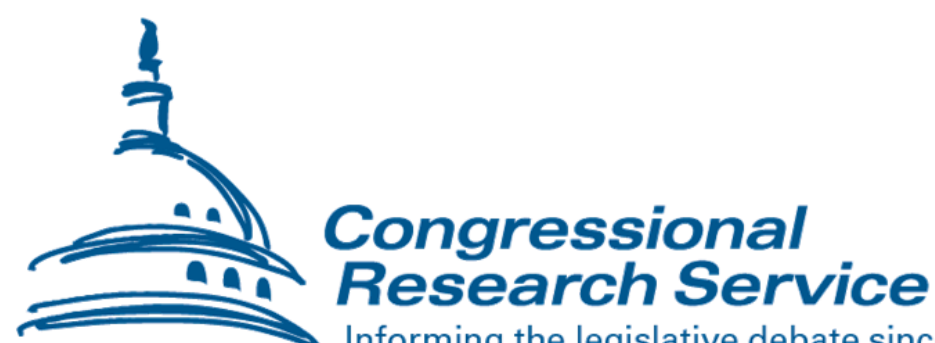

Informing the legislative debate since 1914

\title{
Pakistan's Nuclear Weapons
}

\author{
Paul K. Kerr \\ Analyst in Nonproliferation \\ Mary Beth Nikitin \\ Specialist in Nonproliferation
}

January 14, 2016 


\section{Summary}

Pakistan's nuclear arsenal probably consists of approximately 110-130 nuclear warheads, although it could have more. Islamabad is producing fissile material, adding to related production facilities, deploying additional nuclear weapons, and new types of delivery vehicles. Pakistan's nuclear arsenal is widely regarded as designed to dissuade India from taking military action against Pakistan, but Islamabad's expansion of its nuclear arsenal, development of new types of nuclear weapons, and adoption of a doctrine called "full spectrum deterrence" have led some observers to express concern about an increased risk of nuclear conflict between Pakistan and India, which also continues to expand its nuclear arsenal.

Pakistan has in recent years taken a number of steps to increase international confidence in the security of its nuclear arsenal. Moreover, Pakistani and U.S. officials argue that, since the 2004 revelations about a procurement network run by former Pakistani nuclear official A. Q. Khan, Islamabad has taken a number of steps to improve its nuclear security and to prevent further proliferation of nuclear-related technologies and materials. A number of important initiatives, such as strengthened export control laws, improved personnel security, and international nuclear security cooperation programs, have improved Pakistan's nuclear security.

However, instability in Pakistan has called the extent and durability of these reforms into question. Some observers fear radical takeover of the Pakistani government or diversion of material or technology by personnel within Pakistan's nuclear complex. While U.S. and Pakistani officials continue to express confidence in controls over Pakistan's nuclear weapons, continued instability in the country could impact these safeguards. Furthermore, continued Indian and Pakistani nuclear weapons development could jeopardize strategic stability between the two countries. For a broader discussion, see CRS Report R41832, Pakistan-U.S. Relations, by K. Alan Kronstadt. 


\section{Contents}

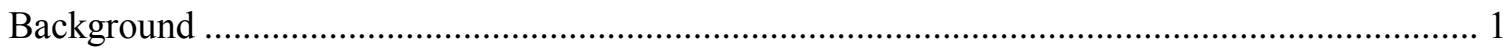

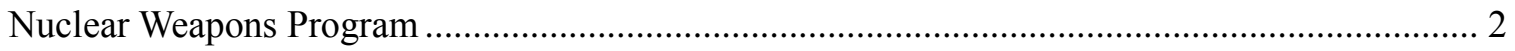

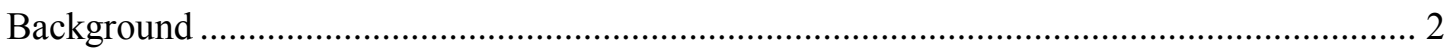

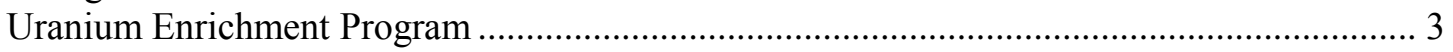

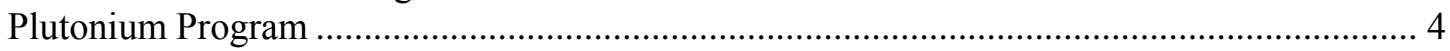

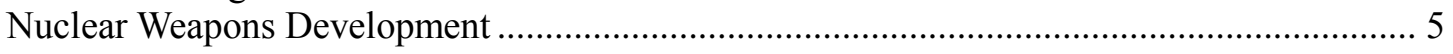

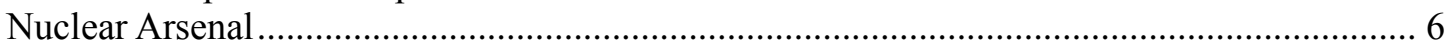

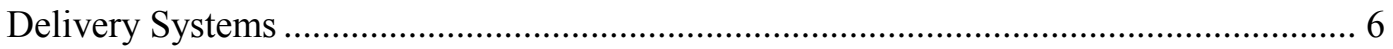

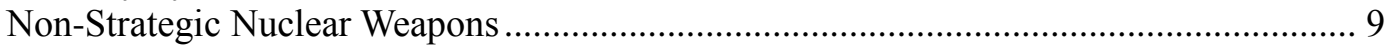

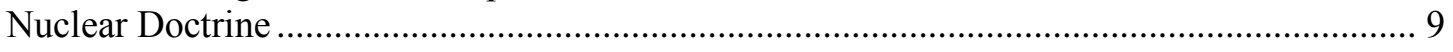

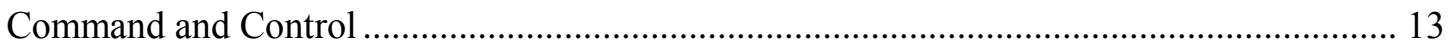

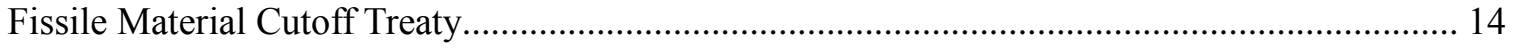

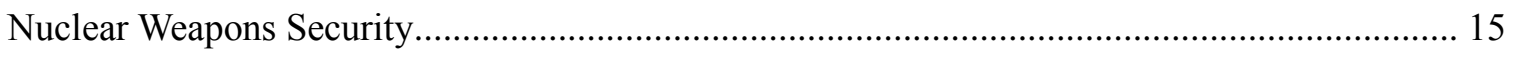

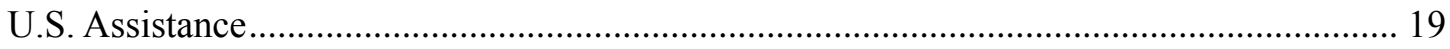

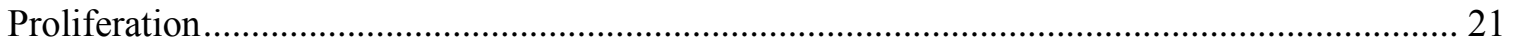

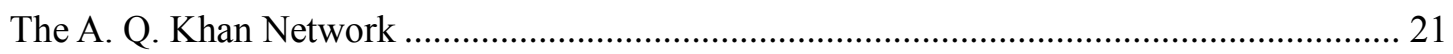

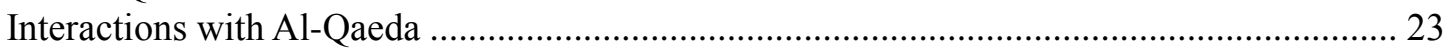

Pakistan's Response to the Proliferation Threat.................................................................. 24

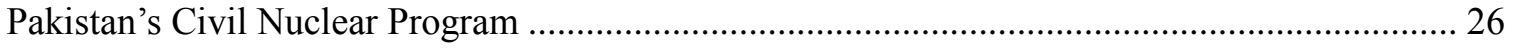

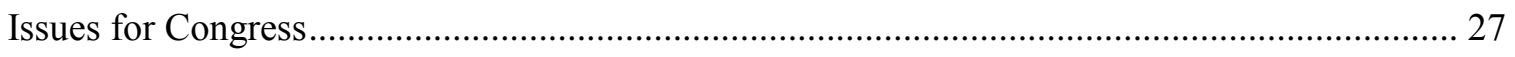

\section{Contacts}

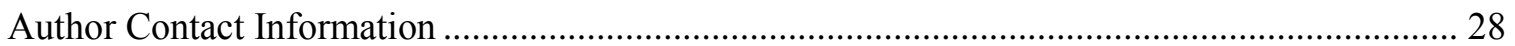




\section{Background}

Chronic political instability in Pakistan and Islamabad's military efforts against the Taliban and al-Qaeda have raised concerns about the security of the country's nuclear weapons. Some observers fear that Pakistan's strategic nuclear assets could be obtained by terrorists or used by elements in the Pakistani government. However, U.S. officials have generally expressed confidence in the security of Pakistan's nuclear weapons.

The collapse or near-collapse of the Pakistani government is probably the most likely scenario in which militants or terrorists could acquire Pakistani nuclear weapons. Gary Samore, thenNational Security Council Coordinator for Arms Control and Non-Proliferation, stated in an April 2011 interview that

The Pakistani government takes the nuclear security threat very seriously, and they've put a lot of resources into trying to make sure that their nuclear facilities and materials and weapons are well secured. There's no lack of recognition that this is a very important issue, and there's no lack of incentive on the part of the Pakistani government to maintain control. What I worry about is that, in the context of broader tensions and problems within Pakistani society and polity - and that's obviously taking place as we look at the sectarian violence and tensions between the government and the military and so forth-I worry that, in that broader context, even the best nuclear security measures might break down. You're dealing with a country that is under tremendous stress internally and externally, and that's what makes me worry. They have good programs in place; the question is whether those good programs work in the context where these broader tensions and conflicts are present. ${ }^{1}$

Pakistani efforts to improve the security of its nuclear weapons have been ongoing and have included some cooperation with the United States; former Pakistani President Pervez Musharraf told a journalist in 2009 that Islamabad has "given State Department nonproliferation experts insight into the command and control of the Pakistani arsenal and its on-site safety and security procedures."2 Moreover, following the 2004 revelations of an extensive international nuclear proliferation network run by Pakistani nuclear official Abdul Qadeer Khan, as well as possible connections between Pakistani nuclear scientists and Al Qaeda, Islamabad has made additional efforts to improve export controls and monitor nuclear personnel. The main security challenges for Pakistan's nuclear arsenal are keeping the integrity of the command structure, ensuring physical security, and preventing illicit proliferation from insiders.

Some observers are also concerned about the risk of nuclear war between India and Pakistan. The two countries most recently came to the brink of full-scale war in 1999 and 2002, and, realizing the dangers, have developed some risk reduction measures to prevent accidental nuclear war. Nevertheless, Pakistan continues to produce fissile material for weapons and appears to be augmenting its weapons production facilities as well as deploying additional delivery vehiclessteps that will enable both quantitative and qualitative improvements in Islamabad's nuclear arsenal. Some observers have argued that Pakistan's expansion of its nuclear arsenal, development of new types of nuclear weapons, and adoption of a doctrine called "full spectrum deterrence" indicate "the growing nuclearization of Pakistan's national security policy." These developments have "sparked international concerns about the safety and security" of the country's

\footnotetext{
${ }^{1}$ Peter Crail, Daniel Horner, and Daryl G. Kimball, "Pursuing the Prague Agenda: An Interview with White House Coordinator Gary Samore," Arms Control Today, May 2011.

${ }^{2}$ Seymour M. Hersh, "Defending the Arsenal: In an Unstable Pakistan, Can Nuclear Warheads be Kept Safe?" The New Yorker, November 16, 2009.
} 
nuclear weapons, as well as raised "concerns that these weapons might be used through

intentional, inadvertent, or accidental launch in a crisis or in limited warfare with India."3

\section{Nuclear Weapons Program ${ }^{4}$}

A 2013 State Department report explains that India and Pakistan's governments view nuclear weapons as "vital to their security," adding that these states'

respective decisions to pursue nuclear weapons stem largely from their troubled bilateral relationship, assessments of threats posed by each other (and China in India's case), perceptions of enhanced national power or status derived from possession of such weapons, and domestic politics. The nuclear programs are popular within each country and are protected by strong institutional and domestic political constituencies. In view of these factors, international pressure over a period of decades has had little direct impact on the attitudes of India and Pakistan concerning nuclear weapons. ${ }^{5}$

Islamabad is expanding its nuclear arsenal and developing of new types of nuclear weapons. Special Representative for Afghanistan and Pakistan Ambassador Richard Olson told the House Committee on Foreign Affairs on December 16, 2015, that the United States is "concerned" about "the pace and the scope of the Pakistan's missile program, including its pursuit of nuclear systems." The administration also worries that "a conventional conflict in Southwest Asia could escalate to include nuclear use as well as the increased security challenges that accompany growing stockpiles," he added.

\section{Background}

Pakistan's nuclear energy program dates back to the 1950s, but it was the loss of East Pakistan (now Bangladesh) in a war with India that probably triggered a January 1972 political decision (just one month later) to begin a secret nuclear weapons program. ${ }^{7}$ Observers point to India's 1974 "peaceful" nuclear explosion as the pivotal moment that gave additional urgency to the program. ${ }^{8}$ During the 1970 s, Pakistan began programs to produce highly-enriched uranium (HEU) and plutonium for use as fissile material for nuclear weapons. HEU and plutonium are the two types of fissile material used in nuclear weapons. Pakistan first produced fissile material for its nuclear weapons using gas-centrifuge-based uranium enrichment technology, which it mastered by the mid-1980s. Gas centrifuges enrich uranium by spinning uranium hexafluoride gas at high speeds to increase the concentration of the uranium-235 isotope.

\footnotetext{
${ }^{3}$ Toby Dalton and Michael Krepon, A Normal Nuclear Pakistan, Stimson Center and Carnegie Endowment for International Peace, 2015.

${ }^{4}$ Pakistan has signed neither the nuclear Nonproliferation Treaty nor the Comprehensive Test Ban Treaty. However, UN Security Council Resolution 1172, which was adopted in 1998 after India and Pakistan's nuclear tests earlier that year, called upon those countries to "stop their nuclear weapon development programmes, to refrain from weaponization or from the deployment of nuclear weapons, to cease development of ballistic missiles capable of delivering nuclear weapons and any further production of fissile material for nuclear weapons."

${ }^{5}$ Report to Congress: Update on Progress toward Regional Nuclear Nonproliferation in South Asia, submitted April 3 , 2013.

6 "Rep. Ed Royce Holds a Hearing on U.S.-Pakistan Relations," House Committee on Foreign Affairs, December 16, 2015.

${ }^{7}$ See, for example, U.S. Department of Defense, Proliferation: Threat and Response, April 1996, p. 37.

${ }^{8}$ According to one account, the government in June 1974 gave the Pakistan Atomic Energy Commission the "official go ahead" to build a nuclear weapon. (Shahid-Ur Rehman, Long Road to Chagai: Untold Story of Pakistan's Nuclear Quest, (Islamabad: Print Wise Publication), 1999. p.53).
} 
Islamabad gained technology for its nuclear weapons program from many sources. This extensive assistance included uranium enrichment technology from Europe and China. ${ }^{9}$ Islamabad has received Chinese and European assistance for at least some of its plutonium program. A 2001 Defense Department report states that "China supplied Pakistan with nuclear material and expertise and has provided critical assistance in the production of Pakistan's nuclear facilities." ${ }^{10}$ This assistance included help during the 1990s with a "plutonium production reactor" and ring magnets from a Chinese entity for Pakistan's enrichment program. ${ }^{11}$ China may also have provided "nuclear weapons design information" to Pakistan. ${ }^{12}$ In addition, China and North Korea have supplied missiles to Pakistan. One 2013 non-governmental report argues that Pakistan has been procuring components for its enrichment program from foreign entities. ${ }^{13}$

\section{Uranium Enrichment Program}

The U.S. and other governments had information during the 1970s that Pakistan was constructing a uranium enrichment facility. ${ }^{14}{ }^{15}$ A.Q. Khan has stated that Pakistan began enriching uranium in 1978 and produced HEU in $1983 .{ }^{16}{ }^{17}$ Pakistan told the United States in 1984 that it would

\footnotetext{
${ }^{9}$ See Nuclear Black Markets: Pakistan, A.Q. Khan and the Rise of Proliferation Networks (London: The International Institute for Strategic Studies), 2007.

${ }^{10}$ U.S. Department of Defense, Proliferation: Threat and Response, January 2001, p. 27.

${ }^{11}$ Ibid., p.18. "Responses to Questions Submitted by Senator Coverdell on Behalf of Senator Bennett," Department of State, August 14, 1996.

${ }^{12}$ Central Intelligence Agency, Chinese Policy and Practice Regarding Sensitive Nuclear Transfers: Special National Intelligence Estimate, January 20, 1983. China transferred a complete nuclear weapon design, according to some reports. (See Nuclear Black Markets, 2007, p. 26; Joby Warrick and Peter Slevin, "Libyan Arms Designs Traced Back to China," Washington Post, February 15, 2004; Albright, David. Peddling Peril: How the Secret Nuclear Trade Arms America's Enemies (New York: Free Press), p. 47.)

${ }^{13}$ David Albright, Andrea Stricker, and Houston Wood, Future World of Illicit Nuclear Trade: Mitigating the Threat, Institute for Science and International Security, July 29, 2013, p.37.

${ }^{14}$ For example, a 1978 memorandum from the National Intelligence Officer for Nuclear Proliferation stated that Pakistan had a uranium enrichment plant "under construction," but added that Islamabad had not yet acquired certain key components., "Monthly Warning Report: Nuclear Proliferation," National Intelligence Officer for Nuclear Proliferation, NFAC-5472-78, December 5, 1978.

${ }^{15}$ According to a 1979 Netherlands government report, which cited "[i]information from reliable sources," Pakistan had a "pilot installation with a very small enrichment capacity." (Dutch Government Report of the Interministerial Working Party Responsible for Investigating “The Khan Affair Report.” October 1979. p. 64.) According to a 1979 Australian intelligence assessment, "the acquisition by Pakistan of a nuclear explosive capability is three to five years away." (Pakistan Nuclear Developments: Action by Australia, Cabinet Minute: Foreign Affairs and Defence Committee, Decision Number 9056, June 26, 1979.)

16 "Nuclear Bomb Was Manufactured in 1984: Dr. Abdul Qadir Khan,” Islamabad Jinnah, July 19, 2010; "Pakistan: Dr Abdul Qadeer Khan Discusses Nuclear Program in TV Talk Show," Islamabad Tonight, Aaj News Television, August 31, 2009. Two non-Pakistani sources appear to at least partly corroborate this account. First, a 1981 State Department draft paper indicated that Pakistan had not "proceeded to the systematic separation of special nuclear materials, or the assembly and deployment of nuclear weapons." (Special Assistant for Nuclear Proliferation Intelligence, National Foreign Assessment Center, Central Intelligence Agency, to Resource Management Staff, Office of Program Assessment et al., "Request for Review of Draft Paper on the Security Dimension of Non-Proliferation," April 9, 1981.) Second, according to a 2008 International Atomic Energy Agency report, A.Q. Khan offered centrifuge enrichment technology to Libya in 1984-a data point apparently corroborating the 1983 date. (Implementation of the NPT Safeguards Agreement in the Socialist People's Libyan Arab Jamahiriya, Report by the Director General, International Atomic Energy Agency, GOV/2008/39, September 12, 2008).

${ }^{17}$ Khan stated in a 2009 television interview that Pakistan stopped producing its first-generation centrifuge in 1983 and started using a more advanced centrifuge. ("Pakistan: Dr Abdul Qadeer Khan Discusses Nuclear Program in TV Talk Show," 2009).
} 
produce only low-enriched uranium (which is not used as fissile material in nuclear weapons), but a 1986 Arms Control and Disarmament Agency (ACDA) memorandum indicates that Islamabad had violated the pledge and added that Pakistan had "overcome the last major obstacle to nuclear weapons by producing enough high enriched uranium for one or more nuclear devices." Pakistan's "HEU production capacity" in 1987 was "sufficient to produce one bomb per year," according to an ACDA memorandum written the next year. ${ }^{19}$ The country's main enrichment facility is a centrifuge plant located at Kahuta; ${ }^{20}$ Pakistan may have other enrichment sites. ${ }^{21}$

\section{Plutonium Program}

A 1985 CIA report described a possible Pakistani plan to "build a plutonium production reactor" ${ }^{22}$ and Pakistan has operated the 40-50 megawatt heavy-water Khushab plutonium production reactor since $1998 .^{23}$ Islamabad has been constructing at least three additional heavy-water reactors, which would expand considerably Pakistan's plutonium production capacity, at the same site; all four reactors at the site are operational, according to reports from nongovernmental experts. ${ }^{24}$ Additionally, Pakistan has a reprocessing plant ${ }^{25}$ at the New Laboratories facility of the Pakistan Institute of Science and Technology (PINSTECH) and is apparently constructing other such plants. ${ }^{26}$ Sources identify 2000 and 2002 as the dates when the PINSTECH plant began operating. ${ }^{27}$ Pakistan also appears to be constructing a second reprocessing plant at PINSTECH ${ }^{28}$ and may be completing a reprocessing plant located at Chasma. ${ }^{29}$

\footnotetext{
${ }^{18}$ Arms Control and Disarmament Agency, "Pakistan's Nuclear Weapons Program and U.S. Security Assistance," Memorandum for the Assistant to the President for National Security Affairs, June 16, 1986.

${ }^{19}$ Arms Control and Disarmament Agency, "Solarz Amendment Applicability to the Pakistani Procurement Case," July 16, 1987.

${ }^{20}$ This plant was completed "[b]y the end of 1980," according to Dr. Samar Mubarakmand, a scientist closely involved with Pakistan's nuclear weapons program. (“A Science Odyssey: Pakistan's Nuclear Emergence Speech,” delivered by Dr. Samar Mubarakmand, November 30, 1998.)

${ }^{21}$ Zia Mian, A.H. Nayyar, R. Rajaraman and M.V. Ramana, "Fissile Materials in South Asia: The Implications of the U.S.-India Nuclear Deal," International Panel on Fissile Materials, September 2006 and David Albright, "Securing Pakistan's Nuclear Infrastructure," in A New Equation: U.S. Policy toward India and Pakistan after September 11 (Washington: Carnegie Endowment for International Peace) May 2002. For a list of Pakistani nuclear facilities, see Nuclear Black Markets: Pakistan, A.Q. Khan and the Rise of Proliferation Networks, (London: The International Institute for Strategic Studies), 2007, p. 19.

${ }^{22}$ Pakistan's Nuclear Weapons Program: Personnel and Organizations: A Research Paper, Central Intelligence Agency, November 1985.

${ }^{23}$ A Pakistani newspaper reported in April 1998 that, according to a "top government source," the reactor had begun operating ("Pakistan's Indigenous Nuclear Reactor Starts Up," The Nation, April 13, 1998). A June 15, 2000 article cited "U.S. officials" who indicated that the reactor had begun operating two years earlier (Mark Hibbs, "After 30 Years, PAEC Fulfills Munir Khan's Plutonium Ambition," Nucleonics Week, June 15, 2000). A 2001 Department of Defense report states that the reactor "will produce plutonium," but does not say whether it was operating (U.S. Department of Defense, Proliferation: Threat and Response, January 2001, p. 27).

${ }^{24}$ David Albright, "Pakistan's Inventory of Weapon-Grade Uranium and Weapon-Grade Plutonium Dedicated to Nuclear Weapons," Institute for Science and International Security, October 19, 2015; Zia Mian, "Pakistan Begins Operating Third Khushab Plutonium Production Reactor," IPFM Blog, International Panel on Fissile Materials, June 30, 2014.

25 "Reprocessing" refers to the process of separating plutonium from spent nuclear fuel.

${ }^{26}$ According to a 1983 State Department document, the New Laboratories facility was capable of extracting small quantities of plutonium, but large enough to "allow for expansion of reprocessing capacity." (The Pakistani Nuclear Program, Department of State, June 23, 1983).

${ }^{27}$ Nuclear Fuel reported in 2000 that, according to "senior U.S. government officials," Islamabad had begun operating a "pilot-scale" reprocessing facility at PINSTECH (Hibbs, June 15, 2000). Former Pakistani Strategic Plans Division (continued...)
} 


\section{Nuclear Weapons Development}

The United States had information during the 1970s and early 1980s that Pakistan was pursuing nuclear weapons designs, but exactly when Pakistan produced a workable nuclear explosive device is unclear. ${ }^{30}$ According to a 1978 State Department cable, the United States estimated that it would take Pakistan "at least" three to five years to produce a nuclear explosive device. ${ }^{31} \mathrm{~A}$ 1982 National Intelligence Estimate (NIE) assessed that Pakistani nuclear testing would be" feasible for the first time" in late 1983 or $1984 .^{32}$ A 1985 National Intelligence Council report states that Pakistan "probably [had] a workable design for a nuclear explosive device" and was "probably ... a year or two away from a capacity to produce enough" highly enriched uranium for such a device. ${ }^{33}$ According to a 1991 NIE, Pakistan had "a viable nuclear weapons design and has components that it could assemble into nuclear devices on short notice." ${ }^{34}$ Islamabad attained such a capability "by the end of the 1980s," said a 1993 report to Congress, apparently from the National Security Council. ${ }^{35}$

Pakistani officials have cited 1984-85 as the period during which Pakistan acquired the capability to detonate a nuclear explosive device. A. Q. Khan stated in an interview published in May 1998 that Islamabad "attained" the capability to detonate such a device "at the end of 1984.",36 Similarly, Khan reportedly stated in a January 2010 speech that Pakistan "had become a nuclear power" in 1984 or $1985 .{ }^{37}$ Moreover, "senior Pakistani politicians" told a Canadian parliamentary committee in June 1998 that Pakistan had "reached the nuclear 'threshold' by 1984-85.",38 According to former Pakistani Strategic Plans Division (SPD) official Feroz Khan, Pakistan developed a nuclear device suitable for explosive testing by the end of 1984, but it "was still a large bomb that could be delivered only by a C-130 cargo aircraft with no assurance of delivery accuracy." 39

\footnotetext{
(...continued)

official Feroz Khan wrote that then-President Pervez Musharraf "made the decision to begin reprocessing plutonium production in 2002." (Khan, Feroz. Eating Grass: The Making of the Pakistani Bomb. (Stanford, California: Stanford University Press), 2012, p. 395.

${ }^{28}$ David Albright and Serena Kelleher-Vergantini, “Pakistan's Chashma Plutonium Separation Plant: Possibly Operational," February 20, 2015. The 2001 Defense Department report states that reprocessing facilities "are under construction," but does not identify any sites (Proliferation: Threat and Response, p. 27).

${ }^{29}$ Construction on the facility was begun during the 1970s with French assistance, but France cancelled its assistance for the project later that decade. See also Albright and Kelleher-Vergantini, February 20, 2015.

${ }^{30}$ See, for example, a 1978 Central Intelligence Agency report, ( (Untitled) RE: Pakistan Strong Motivation to Develop Their Nuclear Capability, April 26, 1978), as well as The Pakistani Nuclear Program, June 23, 1983.

31، Ad Hoc Scientific Committee and Related Topics," January 27, 1978.

${ }^{32}$ Nuclear Proliferation Trends Through 1987, A National Intelligence Estimate, NIE 4-82, July 27, 1982.

${ }^{33}$ The Dynamics of Nuclear Proliferation: Balance of Power and Constraints, National Intelligence Council, September1985.

${ }^{34}$ Prospects for Special Weapons Proliferation and Control, National Intelligence Estimate, NIE 5- 91CV2, July 1991.

${ }^{35}$ Report to Congress on Status of China, India and Pakistan Nuclear and Ballistic Missile Programs, 1993.

36 "Pakistan: Qadeer Khan Interviewed on Pakistan N-Test," The News, May 30, 1998. Khan made a similar claim in February and July 2010 interviews ("Pakistan: Dr A.Q. Khan Condemns Nawaz Sharif for Not Testing Nuclear Bomb," Islamabad Khabrain Online, February 20, 2010; Islamabad Jinnah, July 19, 2010).

${ }^{37}$ Khalid Iqbal, "Pakistan to Never Face 1971-Like Situation Again: AQ Khan," The News, January 10, 2010.

${ }^{38}$ Bill Graham, M.P, Canada and the Nuclear Challenge: Reducing the Political Value of Nuclear Weapons for the Twenty-First Century, Report of the Standing Committee on Foreign Affairs and International Trade, December 1998.

${ }^{39}$ Khan, 2012, p. 189.
} 
In any case, President Bush's failure to certify in 1990 that Pakistan did not "possess a nuclear explosive device" led to a cut-off in military and financial aid under the Pressler Amendment. ${ }^{40}$ After India conducted nuclear weapon tests on May 11 and May 13, 1998, Pakistan's government responded on May 28 and May 30 with six tests in western Pakistan. Test yields were about 10 kilotons and 5 kilotons, according to seismic analysis. ${ }^{41}$ The United States imposed additional sanctions after the tests, but these were lifted after the September 11, 2001, terrorist attacks on the United States.

\section{Nuclear Arsenal}

According to public estimates, Pakistan has about 110-130 nuclear weapons, although it could have more. ${ }^{42}$ According to one unofficial estimate, Pakistan has produced approximately 3,000 kilograms of weapons-grade HEU and approximately 200 kilograms of plutonium for nuclear weapons. ${ }^{43}$ Islamabad continues to produce both HEU and plutonium for nuclear weapons and is developing and deploying a variety of weapons. A 2014 press report, citing Dr. Samar Mubarakmand, a scientist closely involved with the country's nuclear weapons program, states that "Pakistan has over 15 types of nuclear weapons, from large weapons that can be carried on fighter jets to small ones that can be loaded onto ballistic missiles, and even smaller warheads for cruise missiles and tactical nuclear weapons." 44 Pakistan's HEU-based nuclear warheads use an implosion design with a solid core of approximately 15-20 kilograms of HEU. ${ }^{45}$ Pakistan has also produced plutonium-based warheads, ${ }^{46}$ which likely contain approximately 4-6 kilograms of plutonium, according to one expert estimate. ${ }^{47}$ Pakistan has reportedly addressed issues of survivability through pursuing a second strike capability, possibly building hard and deeply buried storage and launch facilities, deploying road-mobile missiles, deploying air defenses around strategic sites, and utilizing concealment measures.

\section{Delivery Systems}

Pakistan has "aircraft and land-based missiles capable of delivering nuclear weapons," according to a 2013 State Department report. ${ }^{48}$ Pakistan has two types of delivery vehicles for nuclear

\footnotetext{
${ }^{40}$ The Pressler Amendment (August 1985) linked aid and military sales to two certification conditions: (1) that Pakistan not possess a nuclear explosive device; and (2) that new aid 'will reduce significantly the risk' that Pakistan will possess such a device. For background summary of sanctions legislation, see CRS Report 98-486, Nuclear Sanctions: Section 102(b) of the Arms Export Control Act and Its Application to India and Pakistan, by Jeanne J. Grimmett, and CRS Report RS22757, U.S. Arms Sales to Pakistan, by Richard F. Grimmett.

${ }^{41}$ Seismic data showed yields less than those officially announced by Pakistan and India. See Gregory van der Vink, Jeffrey Park, Richard Allen, Terry Wallace and Christel Hennet, "False Accusations, Undetected Tests and Implications for the CTB Treaty," Arms Control Today, May 1998.

${ }^{42}$ Hans M. Kristensen and Robert S. Norris, "Pakistani Nuclear Forces, 2015," Nuclear Notebook, Bulletin of the Atomic Scientists. "World Nuclear Forces," SIPRI Yearbook 2015.

${ }^{43}$ David Albright, "Pakistan's Inventory of Weapon-Grade Uranium and Weapon-Grade Plutonium Dedicated to Nuclear Weapons," Plutonium and Highly Enriched Uranium 2015, Institute for Science and International Security, 2015.

44 “Going Nuclear: Plutonium and Uranium Bombs (Pt. 6)," Mainichi, August 12, 2014.

${ }^{45}$ Robert Norris and Hans Kristensen, "Nuclear Notebook: Pakistan's Nuclear Forces, 2007," Bulletin of the Atomic Scientists, May/June 2007.

46 Then-DIA Director Burgess described Pakistan's nuclear weapons as "based primarily on highly enriched uranium" (Burgess, March 10, 2011).

${ }^{47}$ Norris and Kristensen, 2011.

${ }^{48}$ Report To Congress: Update on Progress toward Regional Nuclear Nonproliferation in South Asia, submitted April (continued...)
} 
weapons: aircraft controlled by the Pakistan Air Force and surface-to-surface missiles controlled by the Pakistan Army.

\section{Aircraft}

According to former SPD official Khan, Pakistan in 1995 "had a nuclear device deliverable by fighter aircraft." ${ }^{, 9}$ Islamabad could modify F-16 fighter aircraft purchased from the United States to deliver nuclear weapons; it is widely believed that Pakistan has made the relevant modifications to its U.S.-supplied F-16s. ${ }^{50}$ The contract for provision of an additional 18 aircraft was signed in 2006, as was the contract for the weapons for those aircraft and a contract to perform the mid-life upgrade on Pakistan's F-16A/B model aircraft. ${ }^{51}$ The U.S. government maintains that the sale of additional F-16s to Pakistan will not alter the regional balance of power. ${ }^{52}$ Pakistan will, therefore, expand its F-16 fleet but the planned nuclear-capable portion of the fleet is unclear. Mirage V aircraft may also be used as delivery vehicles. ${ }^{53}$

\section{Missiles}

Then-DIA Director Burgess told the Senate Armed Services Committee on March 10, 2011, that Pakistan is developing new missile systems which, when deployed and added to Islamabad's current ballistic missiles, will enable Pakistan "to strike a variety of targets at ranges of 200-2000 kilometers with both conventional and nuclear payloads." ${ }^{54}$ Several years later, Admiral Ceci Haney, Commander of U.S. Strategic Command, stated in June 2014 event that "Pakistan continues to develop and upgrade their nuclear delivery systems for a full range of platforms, including both ballistic and cruise missiles."

Pakistan continues to carry out ballistic missile tests and notifies India in advance in accordance with an October 2005 bilateral missile pre-notification pact. ${ }^{56}$ Islamabad has several types of nuclear-capable road-mobile ballistic missiles: the solid-fuel Hatf-III (Ghaznavi), with a range of approximately 250-290 kilometers $;{ }^{57}$ the solid-fuel Hatf-IV (Shaheen), with a range of 750

(...continued)

3, 2013.

${ }^{49}$ Khan, 2012 p. 186

${ }^{50}$ The 1993 National Security Council report indicated that Pakistan would use these aircraft to deliver nuclear weapons. See National Security Council, Report to Congress.

${ }^{51}$ See CRS Report RS22757, U.S. Arms Sales to Pakistan.

52 "Release of these systems would not significantly reduce India's quantitative or qualitative military advantage. Release of these modifications to Pakistan will neither affect the regional balance of power nor introduce a new technology as this level of capability or higher already exists in other countries in the region." Defense Security and Cooperation Agency news release, June 28, 2006.

${ }^{53}$ Kristensen and Norris, 2015; Salik, Naeem, The Genesis of South Asian Nuclear Deterrence: Pakistan's Perspective, (Oxford: Oxford University Press), 2009, p. 215.

${ }^{54}$ Burgess, March 10, 2011.

55 "Remarks to the National Defense Industrial Association (NDIA), Air Force Association (AFA) and Reserve Officers Association (ROA) Congressional Breakfast Seminar Series,” June 18, 2014.

56، Agreement Between the Republic of India and the Islamic Republic of Pakistan on Pre-Notification of Flight Testing of Ballistic Missiles." Full text on the Henry L. Stimson Center website: http://www.stimson.org/?SN= SA20060207949.

${ }^{57}$ National Air and Space Intelligence Center, Ballistic and Cruise Missile Threat, 2013; "Pakistan Conducts 'Successful' Training Launch of Surface-To-Surface Ballistic Missile Hatf III,” Inter Services Public Relations, May 8, 2014. 
kilometers $;{ }^{58}$ and the liquid-fuel Hatf-V (Ghauri), with a range of 1,250 kilometers. ${ }^{59}$ According to a 2013 National Air and Space Intelligence Center (NASIC) report, the solid-fuel Hatf-VI (Shaheen-2), with a range of 2,000 kilometers, "probably will soon be deployed." ${ }^{60}$ Pakistan has also tested a version of the Shaheen-1 missile, called the Shaheen-1A, with a range of 900 kilometers. ${ }^{61}$ Additionally, Islamabad has announced flight tests of a nuclear-capable ballistic missile, called the Shaheen-3, with a range of 2,750 kilometers. ${ }^{62}$ This missile, according to Lieutenant General (Retired) Khalid Ahmed Kidwai, former Director General of Pakistan's Strategic Plans Division, is designed to reach Indian islands so that India cannot use them as "strategic bases" to establish a "second strike capability.",63

Pakistan has also announced successful tests of the Hatf-II (Abdali), a short-range ballistic missile with a range of 180 kilometers ${ }^{64}$ which NASIC characterizes as "[d] evelopmental." The missile "carries nuclear as well as conventional warheads," according to a February 2013 government statement. ${ }^{65}$ In addition, Pakistan has also tested its short-range NASR ballistic missile (see below). Pakistan is developing nuclear-capable cruise missiles: the Babur (ground-launched) and the $R a^{\prime}$ 'ad (air-launched), both of which will have estimated ranges of 350 kilometers. ${ }^{66}$ An April

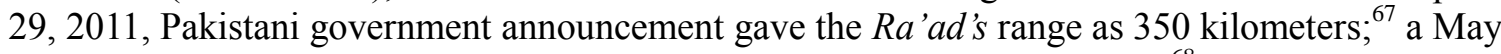
31,2012 , flight test announcement gave the range as "over 350" kilometers. ${ }^{68}$ An October 28 , 2011, Pakistani government announcement gave the Babur's range as 700 kilometers. ${ }^{69}$

\section{Sea-Based Nuclear Weapons}

A Pakistani Foreign Office spokesperson reacted to India's July 26, 2009, launch of its first indigenously built nuclear-powered submarine by asserting that "continued induction of new lethal weapon systems by India is detrimental to regional peace and stability," adding that "[w]ithout entering into an arms race with India, Pakistan will take all appropriate steps to

\footnotetext{
${ }^{58}$ Ballistic and Cruise Missile Threat, 2013. Dr. Samar Mubarakmand gave the missile's range as 700 kilometers during a 2004 television interview ("Capital Talk Special," GEO-TV, May 3, 2004). A January 2008 Pakistani press release also gave the range as 700 kilometers (Inter Services Public Relations, January 25, 2008). However, a May 2010 Pakistani press release gave the range as 650 kilometers (Inter Services Public Relations, May 8, 2010).

${ }^{59}$ Ibid. A November 2014 Pakistani press release gave the range as 1,500 kilometers ("ISPR: Pakistan Conducts 'Successful Training Launch' of Hatf-VI Ballistic Missile,” Inter Services Public Relations, November 13, 2014).

${ }^{60}$ Ballistic and Cruise Missile Threat, 2013. Am April 2015 Pakistani government press release gives the range as 1,300 kilometers. ('ISPR: Pakistan 'Successfully' Conducts 'Training Launch' of Ghauri Missile System, ' Inter Services Public Relations, April 5, 2015).

61 "Revision: Alert: Pakistan Conducts 'Successful' Flight Test of Shaheen-1A Ballistic Missile," Inter Services Public Relations, December 15, 2015.

62 "ISPR: Pakistan Conducts 'Successful' Test-Fire of Shaheen-III Ballistic Missile," Inter Services Public Relations, March 9, 2015; "ISPR: Pakistan Conducts 'Successful Flight Test' of Shaheen-3 Surface-To-Surface Ballistic Missile," Inter Services Public Relations, December 11, 2015.

63 "A Conversation with Gen. Khalid Kidwai," Carnegie International Nuclear Policy Conference 2015, March 23, 2015.

${ }^{64}$ Inter Services Public Relations Press Release, March 11, 2011; Inter Services Public Relations Press Release, February 15, 2013.

${ }^{65}$ Inter Services Public Relations Press Release, February 15, 2013.

${ }^{66}$ Ballistic and Cruise Missile Threat, 2013.

67 "Pakistan: New Cruise Missile Capable of Carrying Nuclear Warheads," Associated Press of Pakistan, April 29, 2011.

${ }^{68}$ Inter Services Public Relations Press Release, May 31, 2012.

${ }^{69}$ Inter Services Public Relations Press Note, "Pakistan Successfully Test Fires Multi-Tube Stealth Cruise Missile," October 28, 2011.
} 
safeguard its security and maintain strategic balance in South Asia." India is developing "submarine-launched ballistic missiles," according to Admiral Haney. ${ }^{70}$ In May 2012, Admiral Mohammad Asif Sandila, then-Chief of Pakistan's Naval Staff, announced "the formal establishment of the Naval Strategic Force Command of Pakistan," describing the force as "the custodian of the nation's $2^{\text {nd }}$ strike capability." 71 General Kidwai indicated during a March 2015 conference that the submarine program is "a work in progress," adding that "this capability will come into play in the next few years.",72

\section{Non-Strategic Nuclear Weapons}

Pakistan is developing what the Director of the Defense Intelligence Agency described in February 2015 as "close-range 'battlefield' nuclear weapons to augment its existing ballistic missiles." ${ }^{, 73}$ Kidwai explained that Pakistan has "opted to develop a variety of short range, low yield nuclear weapons, also dubbed tactical nuclear weapons." "74 For example, Pakistan conducted in April 2011 the first successful flight test of the solid-fuel Hatf IX (NASR), a road-mobile missile with a range of 60 kilometers ${ }^{75}$ which "carries nuclear warheads of appropriate yield with high accuracy" "76 and "has been specially designed to defeat all known Anti Tactical Missile Defence Systems." could increase the risk of nuclear conflict between India and Pakistan. (See "Nuclear Doctrine" section).

\section{Nuclear Doctrine}

The United Kingdom's Foreign and Commonwealth Office has argued that "Pakistan's strategic posture, including nuclear, is clearly framed around its perception of the threat from India.,"78 Similarly, then-DIA Director Burgess told the Senate Armed Services Committee on March 10, 2011, that the "persistent India-Pakistan rivalry drives Islamabad to develop its nuclear infrastructure, expand nuclear weapon stockpiles ... and seek more advanced nuclear warheads and delivery systems, including cruise missiles." 79 Pakistan has repeatedly described its strategic doctrine as "credible minimum deterrence." ${ }^{80}$ Islamabad has pledged no-first-use against non-

\footnotetext{
70 "Remarks to the National Defense Industrial Association (NDIA), Air Force Association (AFA) and Reserve Officers Association (ROA) Congressional Breakfast Seminar Series," June 18, 2014.

71 “Naval Chief Inaugurates Naval Strategic Force Headquarters," Inter Services Public Relations, May 19, 2012.

72 "A Conversation with Gen. Khalid Kidwai," 2015.

${ }^{73}$ Vincent R. Stewart, Lieutenant General, U.S. Marine Corps Director, Defense Intelligence Agency, Worldwide Threat Assessment, Armed Services Committee, February 3, 2015.

74 "A Conversation with Gen. Khalid Kidwai," 2015.

${ }^{75}$ Ballistic and Cruise Missile Threat, 2013.

${ }^{76}$ Inter Services Public Relations Press Release, April 19, 2011.

${ }^{77}$ Inter Services Public Relations Press Release, February 11, 2013.

${ }^{78}$ Memorandum submitted by the Foreign and Commonwealth Office, October 1, 2008. Cited in House of Commons Foreign Affairs Committee, Global Security: Non-Proliferation Fourth Report of Session 2008-09, June 14, 2009.

${ }^{79}$ Burgess, March 10, 2011.

${ }^{80}$ See for example, "Record of the Press Briefing by Pakistan Ministry of Foreign Affairs Spokesperson," May 21, 2015; and Statement by Ambassador Masood Khan, Permanent Representative of Pakistan at the 2014 Session of the United Nations Disarmament Commission, April 7, 2014. A January 13, 2010, statement describing a National Command Authority meeting refers to Pakistan's "policy of credible minimum deterrence."
} 
nuclear-weapon states, but has not ruled out first-use against a nuclear-armed aggressor, such as India. ${ }^{81}$

In 2004, a Pakistani official described four policy objectives for Islamabad's nuclear weapons: deter all forms of external aggression; deter through a combination of conventional and strategic forces; deter counterforce strategies by securing strategic assets and threatening nuclear retaliation; and stabilize strategic deterrence in South Asia. ${ }^{82}$ Pakistani officials have also indicated that this nuclear posture is designed to preserve territorial integrity against Indian attack, prevent military escalation, and counter India's conventional superiority. ${ }^{83}$ Air Commodore Khalid Banuri, Director of Arms Control and Disarmament Affairs in Pakistan's Strategic Plans Division, explained in December 2011 Islamabad's nuclear arsenal is part of an effort "to deny India the space for launching any kind of aggression against Pakistan." ${ }^{84}$ More recently, Islamabad's "nuclear deterrence capability is aimed at maintaining regional stability in South Asia," according to a September 3, 2013 statement from Pakistan's Foreign Ministry spokesperson. Pakistani Foreign Secretary Aizaz Ahmad Chaudhry explained in October 2015 that the country's "nuclear programme is one dimensional: stopping Indian aggression before it happens. It is not for starting a war. It is for deterrence." 85

Despite Islamabad's stated wish to avoid a nuclear arms race with New Delhi, ${ }^{86}$ Pakistan appears to be increasing its fissile production capability and improving its delivery vehicles in order to hedge against possible increases in India's nuclear arsenal and also to deter Indian conventional military action. Indeed, aspects of the credible minimum deterrence doctrine have always been ambiguous and the concept appears to have changed over time. A 2013 State Department report explains that Islamabad has not "publicly articulated clear requirements or quantified what stockpile of nuclear weapons and fissile material would be sufficient to achieve" its credible minimum deterrence posture. ${ }^{87}$ Pakistani officials have argued that a variety of nuclear arsenals could satisfy credible minimum deterrence; Air Commodore Banuri asserted in December 2011 that Pakistan's "deterrence requirement remains dynamic" and a precise number of nuclear weapons to satisfy this requirement "cannot be quantified." ${ }^{88} \mathrm{He}$ also argued that "India's massive conventional military build up, the India-U.S. nuclear deal," and India's pursuit of missile defense systems, forced Pakistan "to make qualitative and quantitative adjustments" to its nuclear arsenal. ${ }^{89}$ Banuri also cited Indian military doctrines that Islamabad describes as prescribing rapid conventional military action against Pakistan.

\footnotetext{
${ }^{81}$ Memorandum from Air Commodore Khalid Banuri, 2011.

${ }^{82}$ Mahmud Ali Durrani, "Pakistan's Strategic Thinking and the Role of Nuclear Weapons," Cooperative Monitoring Center Occasional Paper 37, July 2004.

${ }^{83}$ For an in-depth discussion of minimum deterrence, see Naeem Salik, "Minimum Deterrence and India Pakistan Nuclear Dialogue: Case Study on Pakistan," Landau Network Centro Volta South Asia Security Project Case Study, January 2006.

${ }^{84}$ Memorandum from Air Commodore Khalid Banuri, Director of Arms Control and Disarmament Affairs in the SPD, received by CRS analyst December 4, 2011.

85 “Tactical N-arms to Ward off War Threat, Says FO,” Dawn.com, October 20, 2015.

${ }^{86}$ For example, Ambassador Masood Khan, Pakistan's Permanent Representative to the United Nations, stated on April 7, 2014, that "[w]e do not want an arms race in South Asia." According to a September 2013 National Command Authority statement Pakistan intends to "adhere to the policy of Credible Minimum Deterrence, without entering into an arms race with any other country." (Press Release No PR133/2013-ISPR, September 5, 2013).

${ }^{87}$ Report To Congress, April 3, 2013.

${ }^{88}$ Memorandum from Air Commodore Khalid Banuri, Director of Arms Control and Disarmament Affairs in the SPD, received by CRS analyst December 4, 2011.

${ }^{89}$ Ibid. For details about the 2008 U.S.-India nuclear cooperation agreement, see CRS Report RL33016, U.S. Nuclear (continued...)
} 
Describing the evolution of Pakistan's deterrent, General Kidwai explained that the nuclear program "started with a concept of credible minimum deterrence," but Islamabad "translated it ... to the concept of full spectrum deterrence." ${ }^{, 0}$ Kidwai added that Pakistan developed this doctrine in response to possible Indian rapid conventional military attacks, arguing that some Indian officials were "toying with the idea of finding space for conventional war," because Pakistan lacked non-strategic nuclear weapons and New Delhi did not believe that Islamabad would retaliate with its other nuclear weapons.

Pakistani officials have argued that non-strategic nuclear weapons can increase the credibility of its nuclear deterrent versus Indian conventional military operations. General Kidwai argued that "by introducing the variety of tactical nuclear weapons in Pakistan's inventory, and in the strategic stability debate, we have blocked the avenues for serious military operations by the other side." ${ }^{.1}$ In 2011, Kidwai described the first test of the NASR missile as "a very important milestone in consolidating Pakistan's strategic deterrence capability at all levels of the threat spectrum. " ${ }^{92}$ Some observers have expressed concern that such weapons could increase the risk of nuclear conflict between India and Pakistan for at least two reasons. First, Pakistani military commanders could lose the ability to prevent the use of such weapons, which would be more portable and mobile than Islamabad's current nuclear weapons and delivery vehicles. Second, Pakistani forces may launch non-strategic nuclear weapons in order to counter possible Indian preemptive attacks on those weapons' launch platforms. ${ }^{93}$

Pakistani officials have previously argued that the ambiguity concerning Islamabad's no-first-use policy serves to maintain deterrence against India's conventional superiority; a Foreign Ministry spokesperson stated May 21, 2009, that "there are acquisitions of sophisticated weaponry by our neighbour which will disturb the conventional balance between our two countries and hence, lower the nuclear threshold." Other analysts argue that keeping the first-use option against New Delhi allows Islamabad to conduct operations, such as support for low intensity conflict or proxy war in Kashmir, while effectively deterring India at the strategic level. ${ }^{94}$ In any case, Pakistani statements suggest that the government has a high threshold for using nuclear weapons.

According to a 2012 State Department report, Pakistan previously has said that "nuclear use would be a 'last resort' under circumstances that are 'unthinkable.",95

Nevertheless, Pakistani officials have said for some time that the government may need to increase significantly its nuclear arsenal in response to possible Indian plans to do the same. According to an April 2006 television broadcast, Pakistani officials from the government's National Command Authority (NCA) expressed "concern" that the 2008 U.S.-India nuclear cooperation agreement could tilt the strategic balance between India and Pakistan in favor of the former. The officials suggested that Islamabad may need to increase or improve its nuclear

(...continued)

Cooperation with India: Issues for Congress, by Paul K. Kerr.

90 "A Conversation with Gen. Khalid Kidwai," 2015.

91 "A Conversation with Gen. Khalid Kidwai," 2015.

${ }^{92}$ No PR94/2011-ISPR, April 19, 2011.

${ }^{93}$ See, for example, Feroz Hassan Khan and Ryan W. French, U.S.-Pakistani Nuclear Relations: A Strategic Survey, Report, Number 2014-005, Project on Advanced Systems and Concepts for Countering WMD Naval Postgraduate School, April 2014.

${ }^{94}$ Kanti Bajpai, "No First Use in the India-Pakistan Context," Pugwash Workshop No. 279, November 2002.

${ }^{95}$ Report To Congress: Update on Progress toward Regional Nuclear Nonproliferation in South Asia, submitted March 20, 2012. 
arsenal in order to "to meet all requirements of minimum credible defence deterrence." 96 Similarly, according to the January 2010 statement, the NCA identified "developments detrimental to the objectives of strategic stability in the region," including India's acquisition of "advanced weapons systems" and missile defense systems. The NCA also noted that the 2008 decision by the Nuclear Suppliers Group (NSG) to exempt India from some of its export guidelines, as well as subsequent nuclear fuel supply agreements that New Delhi has concluded with several governments, "would enable India to produce substantial quantities of fissile material for nuclear weapons by freeing up its domestic resources." The statement suggests that Pakistan could increase or improve its nuclear weapons in response to these developments, but does not explicitly say so. Shahzad Chaudhry, a retired Pakistani Air Vice Marshall, argued during a July 18, 2011, U.S. Institute of Peace event that India's stockpile of reactor-grade plutonium is an additional concern for Pakistan. ${ }^{97}$

India has stated that it needs only a "credible minimum deterrent," but New Delhi has never defined what it means by such a deterrent and has refused to sign the Comprehensive Test Ban Treaty. Furthermore, both the 2008 U.S.-India nuclear cooperation agreement and associated NSG decision renewed New Delhi's access to the international uranium market. This access has apparently resulted in more indigenous Indian uranium available for weapons because it will not be consumed by India's newly safeguarded reactors. ${ }^{98}$ Pakistani officials have offered estimates for the number of additional nuclear weapons that New Delhi could build. For example, Wajid Shamsul Hasan, Pakistan's High Commissioner to the United Kingdom, argued in an October 2010 letter to a British newspaper that eight Indian nuclear reactors that will not be subject to International Atomic Energy Agency (IAEA) safeguards have the potential to produce 280 nuclear weapons annually. ${ }^{99}$ India currently has approximately 110-120 nuclear weapons, according to one public estimate. ${ }^{100}$

Whether and to what extent Pakistan intends to continue increasing its nuclear arsenal is unclear. General Kidwai asserted in 2015 that the country's nuclear weapons program "is not open ended" and indicated that Islamabad will not increase the number of weapons significantly during the next 10-15 years. ${ }^{101}$ "There's no need" for Pakistan to develop longer-range missiles than it currently possesses, he added. Current and former Pakistani officials have also argued that the country has achieved its goal of deterring Indian conventional attacks. "War is no more an

\footnotetext{
96 “Pakistan Command Meeting Voices Concern Over Indo-US Nuclear Deal," Pakistan TV, April 12, 2006.

${ }^{97}$ For details about India's reactor-grade plutonium, see International Panel on Fissile Materials, Global Fissile Material Report 2010: Balancing the Books: Production and Stocks, p. 120-122. Reactor-grade plutonium can be used as fissile material in nuclear weapons; see U.S. Committee on the Internationalization of the Civilian Nuclear Fuel Cycle; Committee on International Security and Arms Control, Policy and Global Affairs Division; National Academy of Sciences and National Research Council, Internationalization of the Nuclear Fuel Cycle: Goals, Strategies, and Challenges, 2008, p. 17.

${ }^{98}$ See RL 33016.

99 "Pakistan for Reducing Existing Stocks of Fissile Material: Wajid," Associated Press of Pakistan, October 19, 2010. If Hasan's estimate assumes that Indian weapons designers could build weapons which would each contain approximately 4.5 kilograms of reactor-grade plutonium, then the estimate would be roughly consistent with a 2006 estimate that these reactors could produce 1,250 kilograms of reactor-grade plutonium per year (see Mian et al., 2006).

${ }^{100}$ Robert Norris and Hans Kristensen, "Nuclear Notebook: Indian Nuclear Forces, 2015," Bulletin of the Atomic Scientists, September/October 2015. James N. Miller, Principal Deputy Under Secretary of Defense for Policy, told the House Committee on Armed Services in November 2011 that "India and Pakistan are... increasing the size of their nuclear arsenals, but each is estimated to have fewer weapons than China," which had "a few hundred nuclear weapons." (Statement of Dr. James N. Miller, Principal Deputy Under Secretary of Defense for Policy, Before The House Committee On Armed Services, November 2, 2011.)

101 "A Conversation with Gen. Khalid Kidwai," 2015.
} 
option," Foreign Secretary Aizaz Ahmad Chaudhry stated in October 2015. ${ }^{102}$ Despite its increasing nuclear arsenal, a 2015 Pakistani non-paper states that Islamabad "shall not be the first to resume nuclear testing." 103

\section{Command and Control}

Pakistan's command and control over its nuclear weapons is compartmentalized and includes strict operational security. The government's command and control system is based on "C4I2SR" (command, control, communication, computers, intelligence, information, surveillance and reconnaissance). Islamabad's Strategic Command Organization has a three-tiered structure, consisting of the National Command Authority (NCA), the Strategic Plans Division (SPD), and the Strategic Forces Commands.

General Kidwai asserted in 2015 that the NCA and SPD have "operational control" over Pakistan's nuclear weapons, explaining that "only day-to-day administrative control, some kind of technical control" has been delegated to the country's armed services. ${ }^{104}$ The NCA, established in 2000 and codified in the National Command Authority Act, 2010, supervises the functions and administration of all of Pakistan's organizations involved in nuclear weapons research, development, and employment, as well as the military services that operate the strategic forces. The prime minister, as head of government, is chairperson of the NCA. ${ }^{105}$ The NCA also includes the chair of the joint chiefs of staff; the ministers of defense, interior, foreign affairs, and finance; the director general of the SPD; and the commanders of the Army, Air Force, and Navy. The final authority to launch a nuclear strike requires consensus within the NCA; the chairperson must cast the final vote. The NCA is comprised of two committees, the Employment Control Committee (ECC) and the Development Control Committee (DCC), each of which includes a mix of civilian and military officials. The ECC's functions include establishing a command and control system over the use of nuclear weapons. The DCC "exercises technical, financial and administrative control over all strategic organisations, including national laboratories and research and development organisations associated with the development and modernisation of nuclear weapons." "The NCA also has a "fully automated Strategic Command and Control Support

\footnotetext{
${ }^{102}$ Dawn.com, October 20, 2015.

103 "Pakistan \& The NSG," non-paper from the Embassy of Pakistan circulated on June 3, 2015. Gary Samore included Pakistan in a list of countries "where testing might make sense in terms of" their nuclear weapons programs (Arms Control Today, May 2011). In August 2003 responses to questions for the record from the Senate Select Committee on Intelligence, the CIA stated that Pakistan "almost certainly would conduct nuclear testing in reaction to an Indian nuclear test." However, Dr. Rifaat Hussain of Quad-i-Azam University in Islamabad stated that it is "extremely unlikely" that, absent additional Indian nuclear tests, Pakistan will test nuclear weapons (personal e-mail, October 6, 2011).

104 “A Conversation with Gen. Khalid Kidwai," 2015.

${ }^{105}$ When the NCA was established in 2000, the government's announcement designated the Head of Government, or Prime Minister, as Chairperson. At that time, General Musharraf, as Chief Executive, became Chairperson and stayed in that position after becoming President in 2002. He appointed the Prime Minister as Vice Chairman. However, President Zardari returned the NCA to its original structure when, in a November 2009 re-promulgation of the 2007 NCA Ordinance, he specified that the Prime Minister would be Chairperson, removing himself from that position (this re-promulgation also abolished the position of Vice Chairman). According to Brigadier General (Ret.) Naeem Salik, the change in Chairmanship may have only a symbolic impact on nuclear policy-making, since no changes were made to the Strategic Plans Division itself. A July 2009 Supreme Court decision required that the Ordinances from the Musharraf era be made law.

${ }^{106}$ Nuclear Black Markets: Pakistan, A.Q. Khan and the Rise of Proliferation Networks, (London: The International Institute for Strategic Studies), 2007, p. 111; Pakistan Announcement of Nuclear-Weapons Command-and-Control Mechanism, Associated Press of Pakistan, February 3, 2000. Nuclear Black Markets, pp. 110-111, has organization charts of the NCA and SPD.
} 
System, " which "enables robust Command and Control capability of all strategic assets with round the clock situational awareness in a digitized network centric environment to decision makers." $" 107$

The SPD is headed by a director general from the Army and acts as the secretariat for the NCA. The SPD's functions include formulating Islamabad's nuclear policy, strategy, and doctrine; developing the nuclear chain of command; and formulating operational plans at the service level for the movement, deployment, and use of nuclear weapons. The Army, Air Force, and Navy each have their own strategic force command, but operational planning and control remains with the NCA. The SPD coordinates operational plans with the strategic forces commands. According to current and former Pakistani officials, Islamabad employs a system which requires that at least two, and perhaps three, people authenticate launch codes for nuclear weapons. ${ }^{108}$

The National Command Authority Act, 2010, addresses the problems of the proliferation of nuclear expertise and personnel reliability. It outlines punishable offenses related to breach of confidentiality or leakage of "secured information," gives the SPD authority to investigate suspicious conduct, states that punishment for these offenses can be up to 25 years imprisonment, and applies to both serving and retired personnel, including military personnel, notwithstanding any other laws.

\section{Fissile Material Cutoff Treaty}

Pakistani officials cite their concern about India's recently-acquired ability to expand its nuclear arsenal as a reason for refusing to support negotiations in the Conference on Disarmament (CD), which operates by consensus, on a Fissile Material Cutoff Treaty (FMCT) ${ }^{109}$ Such a treaty would ban the production of fissile material for nuclear weapons. The CD adopted a program of work ${ }^{110}$ in May 2009 that established a working group charged with negotiating an FMCT on the basis of the 1995 "Shannon Mandate." 111 Although Pakistan supported the work plan in 2009, it did not support the adoption of a draft program of work for 2010. ${ }^{112}$ Ambassador Zamir Akram, Pakistan's Permanent Representative to the CD, stated on February 18, 2010, that Islamabad had supported the 2009 program of work ${ }^{113}$ because the government had believed that the Obama Administration might reverse U.S. policy on nuclear cooperation with India.

\footnotetext{
${ }^{107}$ Inter Services Public Relations Press Release, November 28, 2012.

${ }^{108}$ See P. Cotta-Ramusino and M. Martellini, "Nuclear Safety, Nuclear Stability And Nuclear Strategy In Pakistan: A Concise Report Of A Visit By Landau Network - Centro Volta,” January 14, 2002. Available at http://www.pugwash.org/september11/pakistan-nuclear.htm; Kenneth N. Luongo and Brig. Gen. (Ret.) Naeem Salik, "Building Confidence in Pakistan's Nuclear Security," Arms Control Today, December 2007; Robin Walker, "Pakistan's Evolution as a Nuclear Weapons State: Lt. Gen. Khalid Kidwai's CCC Address, Strategic Insights, November 1, 2006.

${ }^{109}$ For more information about the treaty, see CRS Report RL33865, Arms Control and Nonproliferation: A Catalog of Treaties and Agreements, by Amy F. Woolf, Paul K. Kerr, and Mary Beth D. Nikitin.

${ }^{110}$ Decision for the Establishment of a Programme of Work for the 2009 Session, Conference on Disarmament, CD/1864, May 29, 2009.

${ }^{111}$ Report of Ambassador Gerald E. Shannon of Canada on Consultations on the Most Appropriate Arrangement to Negotiate a Treaty Banning the Production of Fissile Material for Nuclear Weapons or Other Nuclear Explosive Devices, CD/1299, March 24, 1995.

${ }^{112}$ Draft Decision for the Establishment of a Programme of Work for the 2010 Session, Conference on Disarmament, CD/1889, July 6, 2010. Also see Statement by Ambassador Zamir Akram, Permanent Representative of Pakistan to the Conference on Disarmament, August 31, 2010.

${ }^{113}$ Statement by Ambassador Zamir Akram, February 18, 2010.
} 
Pakistan, which is widely regarded as the main opponent to the start of negotiations, ${ }^{114}$ argues that a treaty on fissile material should not only prohibit the production of new material, but should also require states with such material to reduce their stocks. ${ }^{115}$ A treaty without such a requirement, according to Pakistan, will put the country at a disadvantage with respect to India because of what Islamabad characterizes as New Delhi's larger fissile material stocks and production capability. ${ }^{116}$ Although the Shannon Mandate states that it "does not preclude any delegation" from proposing the inclusion of existing stocks in the negotiations, Islamabad argues that the $\mathrm{CD}$ ought to determine the treaty's scope prior to beginning negotiations. ${ }^{117}$

\section{Nuclear Weapons Security}

According to a 2001 Department of Defense report, Islamabad's nuclear weapons "are probably stored in component form," "which suggests that the nuclear warheads are stored separately from delivery vehicles. According to some reports, the fissile cores of the weapons are separated from the non-nuclear explosives. ${ }^{119}$ According to Dr. Mubarakmand, the scientist closely involved with the country's nuclear weapons program, Pakistani nuclear weapons are "stored in three to four different parts at three to four different locations," adding that, "[i]f a nuclear weapon doesn't need to be launched, then it is never available in assembled form." ${ }^{120}$ The 2001 Defense Department report says that Pakistan can probably assemble its weapons fairly quickly. ${ }^{121}$ It warrants mention that, although separate storage may provide a layer of protection against accidental launch or prevent theft of an assembled weapon, it may be easier for unauthorized people to remove a weapon's fissile material core if it is not assembled. Dispersal of the assets may also create more potential access points for acquisition and may increase the risk of diversion. ${ }^{122}$

As the United States prepared to attack the Afghan Taliban after September 11, 2001, thenPresident Musharraf reportedly ordered that Pakistan's nuclear arsenal be redeployed to "at least six secret new locations." ${ }^{23}$ This action came at a time of uncertainly about the future of the region, including the direction of U.S.-Pakistan relations. Islamabad's leadership was uncertain whether the United States would decide to conduct military strikes against Pakistan's nuclear assets if the government did not assist the United States against the Taliban. Indeed, then-

\footnotetext{
${ }^{114}$ Zia Mian and A.H. Nayyar, "Playing the Nuclear Game: Pakistan and the Fissile Material Cutoff Treaty," Arms Control Today, April 2010.

115 Akram, February 18, 2010; Ibid.

${ }^{116}$ Ibid. See also Permanent Mission of Pakistan to the United Nations and Other International Organizations, “Working Paper by Pakistan: Elements of a Fissile Material Treaty (FMT)," August 21, 2015.

${ }^{117}$ Akram, August 31, 2010.

${ }^{118}$ Proliferation: Threat and Response, p. 27.

119 Joby Warrick, "Pakistan Nuclear Security Questioned; Lack of Knowledge About Arsenal May Limit U.S. Options," Washington Post, November 11, 2007; Peter Wonacott, "Inside Pakistan's Drive To Guard Its A-Bombs," Wall Street Journal, November 29, 2007; David E. Sanger, “Trust Us: So, What About Those Nukes?," New York Times, November 11, 2007; Nuclear Black Markets, 2007, p.33; Cotta-Ramusino and Martellini, 2002.

120 "Pakistan Refutes Saudi Funding, Weapons Claims," World Bulletin, November 9, 2013.

${ }^{121}$ Proliferation: Threat and Response, p. 28.

122 See Graham Allison, “What About the Nukes?” Newsweek Web, December 28, 2007.

${ }^{123}$ Molly Moore and Kamran Khan, "Pakistan Moves Nuclear Weapons - Musharraf Says Arsenal Is Now Secure," Washington Post, November 11, 2001.
} 
President Musharraf cited protection of Pakistan's nuclear and missile assets as one of the reasons for Islamabad's dramatic policy shift. ${ }^{124}$

These events, in combination with the 1999 Kargil crisis, the 2002 conflict with India at the Line of Control, and revelations about the A. Q. Khan proliferation network, inspired a variety of reforms to secure the nuclear complex. Risk of nuclear war in South Asia ran high during the 1999 Kargil crisis, when, according to former William J. Clinton administration officials, the Pakistani military began preparing missiles to deliver nuclear weapons. ${ }^{125}$ It should be noted that, even at the high alert levels of 2001 and 2002, there were no reports of Pakistan mating the warheads with delivery systems. ${ }^{126}$

In the fall of 2007 and early 2008, some observers expressed concern about the security of the country's arsenal if political instability were to persist. ${ }^{127}$ Former Prime Minister Benazir Bhutto said in a November 5, 2007, interview that, although then-President Musharraf claimed to be in firm control of the nuclear arsenal, she feared this control could weaken due to instability in the country. ${ }^{128}$ Similarly, Michael Krepon of the Henry L. Stimson Center has argued that "a prolonged period of turbulence and infighting among the country's President, Prime Minister, and Army Chief" could jeopardize the army's unity of command, which "is essential for nuclear security." ${ }^{129}$ U.S. military officials also expressed concern about the security of Pakistan's nuclear weapons. ${ }^{130}$ Experts also worry that while nuclear weapons are currently under firm control, with warheads disassembled, technology could be sold off by insiders during a worsened crisis. ${ }^{131}$

Chairman of the Joint Chiefs of Staff Admiral Michael Mullen described U.S. concern about the matter during a September 22, 2008, speech:

To the best of my ability to understand it - and that is with some ability - the weapons there are secure. And that even in the change of government, the controls of those weapons haven't changed. That said, they are their weapons. They're not my weapons. And there are limits to what I know. Certainly at a worst-case scenario with respect to Pakistan, I worry a great deal about those weapons falling into the hands of terrorists and either being proliferated or potentially used. And so, control of those, stability, stable control of those weapons is a key concern. And I think certainly the Pakistani leadership that I've spoken with on both the military and civilian side understand that. ${ }^{132}$

\footnotetext{
124 "Partial transcript of Pakistan President Musharraf's televised speech asking the people of Pakistan to support his course of action," September 19, 2001.

${ }^{125}$ Bruce Riedel, “American Diplomacy and the 1999 Kargil Summit at Blair House," Center for the Advanced Study of India, Policy Paper Series, 2002.; Strobe Talbott, Engaging India: Diplomacy, Democracy, and the Bomb, (Brookings Institution Press: Washington, DC), 2004, pp. 161-62; Aziz Haniffa, "Pressure Must Also be Put on India to De-Escalate," India Abroad, June 14, 2002. Former SPD official Khan's book contests these claims (Khan, 2012. pp. 314-15).

${ }^{126}$ Lavoy, 2006.

127 “Opinions Mixed on Pakistani Nuclear Security,” Global Security Newswire, November 6, 2007.

${ }^{128}$ Also see comments by David Albright in the same interview ("Pakistan in Crisis: Interview with Benazir Bhutto," CNN, November 5, 2007).

129 "U.S.-Pakistan Strategic Relations," Statement before the Committee on Senate Homeland Security and Governmental Affairs Subcommittee on Federal Financial Management, Government Information, Federal Services, and International Security June 12, 2008.

130 "Lieutenant General Carter Ham Holds a Defense Department Briefing," CQ Transcripts, November 7, 2007.

${ }^{131}$ Also see comments by David Albright in "Pakistan in Crisis," 2007.

${ }^{132}$ Remarks by Admiral Michael Mullen, Chairman of the Joint Chiefs of Staff, to the L.A. World Affairs Council, September 22, 2008.
} 
However, U.S. officials have expressed confidence regarding the security of Islamabad's nuclear weapons. Defense Intelligence Agency Director Stewart stated in February 2015 that "Pakistan continues to take steps to improve the security of its nuclear arsenal." ${ }^{, 133}$ More recently, White House Press Secretary Josh Earnest stated on October 15, 2015, that

we continue to have confidence that the government of Pakistan is well aware of the range of potential threats to its nuclear arsenal, and we continue to be confident that Pakistan has a professional and dedicated security force that understands the importance and the high priority that the world places on nuclear security. ${ }^{134}$

Ambassador Olson told the House Foreign Affairs Committee on December 16, 2015, that Washington has "confidence in the capabilities of ... the Pakistani security forces to control and secure their nuclear weapons," adding that Islamabad has "specifically taken into account the insider threat" to its nuclear arsenal. More recently, a former administration official wrote in September 2014 that

The likelihood [of] terrorists obtaining nuclear weapons or nuclear material from Pakistani facilities is currently very low because of the extraordinary measures the Pakistan government and military have taken over the last decade... Pakistani nuclear materials do not pose the concerns that they once did. ${ }^{135}$

U.S. officials have stated that U.S. knowledge of Pakistan's arsenal is limited. For example, thenChairman of the Joint Chiefs of Staff Mullen stated during a May 14, 2009, hearing before the Senate Armed Services Committee that "we're limited in what we actually know" about Islamabad's nuclear arsenal.

Other governments have also voiced opinions regarding the security of Pakistan's nuclear arsenal. For example, Indian National Security Adviser M. K. Narayanan said that the arsenal is safe and has adequate checks and balances. ${ }^{136}$ Similarly, then-Secretary of State for Foreign and Commonwealth Affairs David Miliband told the Charlie Rose Show on December 15, 2008, that Islamabad's nuclear weapons "are under pretty close lock and key." Furthermore, according to Director of the French General Directorate of External Security Erard Corbin de Mangoux, Pakistan's military and civilian leaders have a "sense of responsibility" to maintain control over the country's nuclear weapons; these leaders "know that the international status to which they aspire depends directly on their ability to exercise complete control over such an instrument of power," he argued in an interview published in spring $2010 .{ }^{137}$

Other non-U.S. officials, however, have sounded somewhat less optimistic. For example, Russian Deputy Prime Minister Sergei Ivanov said in a March 24, 2009, television interview that Moscow is "very much concerned" about the security of Pakistan's arsenal. ${ }^{138}$ Indian officials expressed concerns about the security of Pakistan's nuclear arsenal following the May 2011 insurgent attack on the Karachi military installation. ${ }^{139}$

\footnotetext{
${ }^{133}$ Stewart, February 3, 2015.

${ }^{134}$ White House Press Secretary Josh Earnest Holds White House Regular News Briefing, October 15, 2015.

${ }^{135}$ Email to author, September 11, 2014.

136 "Pak Nukes Safely Guarded, Says Narayanan," The Press Trust of India, December 16, 2007.

${ }^{137}$ Isabelle Lasserre, "Intelligence and the New Threats," Politique Internationale, January 1-March 31, 2010.

${ }^{138}$ Lyubov Pronina and Ellen Pinchuk, "Russia 'Concerned' About Security of Pakistan's Nuclear Arsenal," Bloomberg, March 25, 2009.

139 “Safety of Pakistan’s Nukes a Global Concern: India,” Indo-Asian News Service, May 25, 2011.
} 
Pakistani officials have consistently expressed confidence in the security of the country's nuclear arsenal. ${ }^{140}$ Then-President Musharraf stated in November 2007 that Pakistan's nuclear weapons are under "total custodial controls." 141 According to Pakistan's 2014 Nuclear Security Summit statement, the country's "nuclear security regime is anchored in the principle of multi-layered defense for the entire spectrum of any nuclear threat" and includes a "specially trained Special Response Force," an "integrated intelligence system" and "[f]orce validation exercises." "The SPD "has two separate divisions to oversee security and intelligence, with more than 25,000 personnel between them," according to SPD official Adil Sultan. ${ }^{143}$

The May 2011 U.S. strike that killed Al Qaeda leader Osama bin Laden generated a public discussion in Pakistan as to whether a country such as India or the United States could successfully attack and destroy Pakistan's nuclear weapons. ${ }^{144}$ Responding to these concerns, then-Prime Minster Gilani stated May 25, 2011, that the country's "strategic assets are well protected and our capability to defend our sovereignty, territorial integrity and liberties of our people, is very much in place." 145

In addition to the above scenarios, the security of Pakistan's nuclear weapons could also be jeopardized by another conflict between India and Pakistan, Michael Krepon argued, explaining that an "escalating war with nuclear forces in the field would increase the probability of accidents, miscalculations, and the use of nuclear weapons" because

[w] hen tensions rise precipitously with India, the readiness level of Pakistan's nuclear deterrent also rises. Because the geographical coordinates of Pakistan's main nuclear weapon storage sites, missile, and air bases can be readily identified from satellites - and therefore targeted by opposing forces - the dictates of deterrence mandate some movement of launchers and weapons from fixed locations during crises. Nuclear weapons on the move are inherently less secure than nuclear weapons at heavily-guarded storage sites. Weapons and launchers in motion are also more susceptible to "insider" threats and accidents. ${ }^{146}$

Such a war, Krepon added, would also place stress on the army's unity of command. Krepon has also pointed out that Islamabad faces a dilemma, because less-dispersed nuclear weapons may be more vulnerable to a disarming military strike from India. ${ }^{147}$

\footnotetext{
${ }^{140}$ Air Commodore Khalid Banuri, Director of Arms Control and Disarmament Affairs in the SPD, stated in a 2008 interview that Islamabad has "consistently augmented" its nuclear weapons security since 1998 (Ahmed Quraishi, "Interview: Air Commodore Khalid Banuri - 'Don't Mess With Pakistan'," January 17, 2008), http://www.globalpolitician.com/24013-pakistan.

141 "Pakistan Nukes Under Control: Musharraf,” Agence France Presse, November 13, 2007.

142 "Nuclear Security Summit 2014 National Statement: Pakistan."

143 Adil Sultan, “In Defence of Pakistan's Nuclear Management," IISS Voices, June 26, 2015.

144 Jane Perlez, "Pakistan Army Under Scrutiny After U.S. Raid," New York Times, May 5, 2011; Zahid Hussain, Matthew Rosenberg and Jeremy Page, “After Raid, Confused Response,” The Wall Street Journal, May 9, 2011; Toby Dalton and George Perkovich, "Beware Decline in Pakistani Relations," Politico, May 16, 2011.

${ }^{145}$ Press Information Department, "Prime Minister Gilani's Opening Statement at the Defence Committee of the Cabinet," Pakistan Official News, May 25, 2011.

${ }^{146}$ Krepon, June 12, 2008.

${ }^{147}$ Michael Krepon, “Complexities of Nuclear Risk Reduction in South Asia,” The Hindu, May 29, 2009.
} 


\section{U.S. Assistance}

During former Secretary of State Condoleezza Rice's January 2005confirmation hearing, thenSenator John Kerry asked what would happen to Pakistan's nuclear weapons in the event of a radical Islamic coup in Islamabad, Secretary Rice answered, "[w]e have noted this problem, and we are prepared to try to deal with it," suggesting that the United States had plans to secure Pakistani nuclear weapons in case of a loss of control by the Pakistani government ${ }^{148} \mathrm{On}$ November 12, 2007, responding to press reports about this contingency, a Pakistan Foreign Office spokesperson said, "Pakistan possesses adequate retaliatory capacity to defend its strategic assets and sovereignty," emphasizing that Islamabad's nuclear weapons have been under "strong multilayered, institutionalized decision-making, organizational, administrative and command and control structures since 1998." "The issue of U.S. contingency plans to take over Pakistani strategic assets was raised again in the press following Benazir Bhutto's assassination, and was met with similar assurances by Pakistan's government. ${ }^{150}$

Responding to a report detailing alleged U.S.-Pakistani discussions regarding contingency plans for U.S. forces to help secure Islamabad's nuclear weapons, a Pakistan Foreign Office spokesperson stated on November 8, 2009, that Pakistan "does not require any foreign assistance in this regard." Pakistan will never "allow any country to have direct or indirect access to its nuclear and strategic facilities," the spokesperson said, adding that "no talks have ever taken place on the issue of the security of Pakistan's nuclear arsenal with US officials." 151 ThenSecretary of Defense Gates stated in January 2010 that the United States has "no intention or desire to take over any of Pakistan's nuclear weapons." 152

The United States reportedly offered nuclear security assistance to Pakistan soon after September $11,2001 .{ }^{153}$ U.S. assistance to Islamabad, which must comply with nonproliferation guidelines, has reportedly included the sharing of best practices and technical measures to prevent unauthorized or accidental use of nuclear weapons, as well as contribute to physical security of storage facilities and personnel reliability. ${ }^{154}$ As noted above, Islamabad employs a system requiring that at least two, and perhaps three, people authenticate launch codes for nuclear weapons. ${ }^{155}$ Security at nuclear sites in Islamabad is the responsibility of a 10,000-member security force, commanded by a two-star general. Former Pakistani military officials have said

\footnotetext{
148 "The Nomination of Dr. Condoleezza Rice to be Secretary of State," Hearings before the Senate Foreign Relations Committee, January 18 and 19, 2005. The concept of a contingency plan to take over Pakistan's nuclear assets was first written about by Seymour Hersh, "Watching the Warheads," The New Yorker, November 5, 2001.

149 "Strategic Assets Are Safe, Says FO," Dawn, November 12, 2007.

150 "Pentagon Readies Plan for Pakistan's Nuclear Arsenal," The Guardian, December 28, 2007. For a discussion of executing such a plan, see Shaun Gregory, "The Security of Nuclear Weapons in Pakistan," Pakistan Security Research Unit Brief Number 22, University of Bradford, November 18, 2007. Available at http://spaces.brad.ac.uk:8080/ download/attachments/748/Brief_22finalised.pdf

151 "Pakistan Foreign Office Rejects U.S. Media Report on Nuclear Arsenal," Associated Press of Pakistan, November 9, 2009.

152 "Express TV Interview," January 21, 2010.

${ }^{153}$ Alex Wagner, "U.S. Offers Nuclear Security Assistance to Pakistan,” Arms Control Today, December 2001.

${ }^{154}$ Joby Warrick, “U.S. Has Concerns Over Security of Pakistan's Nuclear Weapons,” The Washington Post, November 11, 2007; David Sanger and William Broad, "U.S. Secretly Aids Pakistan in Guarding Nuclear Arms," The New York Times, November 17, 2007.

${ }^{155}$ Mubarakmand provided some details about Pakistan's use of such codes in a 2004 interview ("Capital Talk Special," GEO-TV, May 3, 2004).
} 
Pakistan has developed Permissive Action Links (PALs) for its warheads without U.S. assistance. ${ }^{156}$ PALs require a code to be entered before a weapon can be detonated.

Former Deputy Secretary of State Richard Armitage confirmed in a November 2007 interview that there has been U.S. assistance in securing Pakistani nuclear weapons, explaining that the United States was unlikely to intervene militarily in a crisis in Pakistan because "we have spent considerable time with the Pakistani military, talking with them and working with them on the security of their nuclear weapons. I think most observers would say that they are fairly secure. They have pretty sophisticated mechanisms to guard the security of those." ${ }^{157}$ Rolf MowattLarssen, former Director of the Office of Intelligence and Counterintelligence at the U.S. Department of Energy, pointed out in May 2009 that "there's not a lot of transparency into" how Islamabad spends the U.S. funds, but he nevertheless characterized them as "money well spent." 158 A Pakistani official said in November 2009 that Pakistan reserves the right to "pick and choose" the nuclear security measures it will undertake, adding that Islamabad will only accept such measures that are "non-intrusive."

The extent to which Pakistan has shared information about its nuclear arsenal with the United States is unclear. Although, as noted, former President Musharraf has acknowledged that Islamabad has shared some information, General Tariq Majid, then-chair of Pakistan's Joint Chiefs of Staff Committee, stated November 9, 2009, that "there is absolutely no question of sharing or allowing any foreign individual, entity or a state, any access to sensitive information about our nuclear assets." 160 Air Commodore Banuri indicated in a 2008 interview that Islamabad accepts U.S. "education and awareness, but in a completely non-intrusive way," adding that Pakistan has "some rudimentary equipment and some training" from the United States. Banuri described U.S. access to Pakistan's nuclear weapons facilities as a "red line" that Islamabad will not cross. ${ }^{161}$

The U.S. government has also reportedly offered assistance to secure or destroy radioactive materials that could be used to make a radioactive dispersal device, and to ship highly enriched uranium used in the Pakistani civilian nuclear sector out of the country. ${ }^{162}$ Pakistan's response to these proposals is unclear, and downturns in the bilateral relationship overall may have complicated efforts to make progress in this area.

It is worth noting that, according to some observers, spent fuel from Pakistan's Karachi and Chasma nuclear power plants could be vulnerable to theft or attack. ${ }^{163}$ However, Pakistani officials have expressed confidence in the security of its facilities ${ }^{164}$ and have said that Islamabad

\footnotetext{
${ }^{156}$ General Kidwai has stated that "if a country can make complex nuclear weapons and ballistic cruise missiles grant it that PALs is a far simpler technology" (cited in Martellini, 2008).

157 “A Conversation With Former Deputy Secretary of State Richard Armitage," PBS: The Charlie Rose Show, November 6, 2007.

158 Ben Arnoldy, "Could Taliban Get Keys to Pakistan's A-Bomb? Experts See the Islamic Fighters as Less of a Risk than Radical Insiders Gaining Access to Nuclear Materials," The Christian Science Monitor, May 15, 2009.

${ }^{159}$ Mariana Baabar, "Pak N-safety Plan," The News International, November 10, 2009.

${ }^{160}$ Ibid.

${ }^{161}$ Quraishi, January 17, 2008.

${ }^{162}$ Bryan Bender, "Pakistan, US in Talks on Nuclear Security," The Boston Globe, May 5, 2009.

${ }^{163}$ Abdul Mannan, "Preventing Nuclear Terrorism in Pakistan: Sabotage of a Spent Fuel Cask or a Commercial Irradiation Source in Transport," in Pakistan's Nuclear Future, 2008; Martellini, 2008. Some analysts argue that spent nuclear fuel is more vulnerable when being transported.

${ }^{164}$ Martellini, 2008.
} 
has no plans to transport spent fuel from either reactor. Moreover, the Pakistan Nuclear Regulatory Authority (PNRA) has a Nuclear Security Action Plan, which includes a description of regulations for handling spent nuclear fuel. The PNRA states that Pakistan follows IAEA physical protection standards.

\section{Proliferation}

A fundamental aspect of nuclear security is ensuring that personnel with sensitive knowledge do not transfer that expertise. Although Pakistan has made significant reforms in this area, many observers continue to be concerned that other states or terrorist organizations could obtain material or expertise related to nuclear weapons from elements in Pakistan. ${ }^{165}$

\section{The A. Q. Khan Network ${ }^{166}$}

Proliferation networks stemming from Pakistan have their roots in the effort to develop a Pakistani nuclear bomb. Beginning in the 1970s, Pakistan used extensive clandestine procurement networks to obtain technology for its own nuclear weapons program. A report from Pakistan's Inter-Services Intelligence published September 15, 2011, stated that Pakistan, as an

under-developed country with no industrial infra-structure, had to buy each and every bit of material and piece of equipment surreptitiously from abroad in the open market and had to establish a network of cover companies within the country and outside to by-pass embargoes and import all the necessary items. ${ }^{167}$

Former Pakistani nuclear scientist A. Q. Khan directed this procurement and subsequently used a similar network to supply Libya, North Korea, and Iran with designs and materials related to uranium enrichment. ${ }^{16}$

\footnotetext{
${ }^{165}$ For more information on Pakistani proliferation, see CRS Report RL33192, U.S.-China Nuclear Cooperation Agreement, by Mark Holt, Mary Beth D. Nikitin, and Paul K. Kerr; CRS Report RL32745, Pakistan's Nuclear Proliferation Activities and the Recommendations of the 9/11 Commission: U.S. Policy Constraints and Options, by Richard P. Cronin, K. Alan Kronstadt, and Sharon Squassoni. Also see CRS Report RL33498, Pakistan-U.S. Relations, by K. Alan Kronstadt.

${ }^{166}$ For a description of the network's activities and their implications, see R.S. Kemp, "The Nonproliferation Emperor Has No Clothes: The Gas Centrifuge, Supply-Side Controls, and the Future of Nuclear Proliferation," International Security, Spring 2014. See also Nuclear Black Markets: Pakistan, A.Q. Khan and the Rise of Proliferation Networks (London: The International Institute for Strategic Studies), 2007, and David Albright, Peddling Peril: How the Secret Nuclear Trade Arms America's Enemies, The Institute for Science and International Security, 2010.

${ }^{167}$ Available at http://www.foxnews.com/world/2011/09/16/aq-khan-report-isi/\#ixzz1 Y9ZIgsQV.

${ }^{168}$ Libya obtained uranium enrichment technology and nuclear weapons designs that could support a nuclear weapons program. North Korea currently has a plutonium-based nuclear weapons program and may also have a uranium-based nuclear weapons program. The United States has suspected Iran of pursuing both plutonium- and uranium-based nuclear weapons programs. Such activity has been of historic concern; a 1979 State Department memorandum stated that Libya, Iraq, or Iran "might be prepared to provide economic support" to Islamabad "in exchange for nuclear cooperation from Pakistan." (Department of State Action Memorandum, "PRC Paper on South Asia," March 23, 1979). Additionally, a 1979 memorandum from the National Intelligence Officer for Nuclear Proliferation stated that Pakistan "might already have been induced to share with identified foreigners some sensitive nuclear equipment and to propose terms for possible future nuclear cooperation with Saudi Arabia, Libya, or Iraq." ("Monthly Warning Report - Nuclear Proliferation," NFAC - 3871-79, July 24, 1979).

${ }^{169}$ The network also supplied Libya with "documents related to the design and fabrication of a nuclear explosive device," according to the IAEA (Implementation of the NPT Safeguards Agreement in the Socialist People's Libyan Arab Jamahiriya, GOV/2008/39, September 12, 2008). However, these documents lacked "important parts" for making a nuclear weapon, according to former IAEA Director-General Mohamed ElBaradei (The Age of Deception: Nuclear (continued...)
} 
The current status of Pakistan's nuclear export network is unclear, although most official U.S. reports indicate that, at the least, it has been damaged considerably. Then-Director of National Intelligence John D. Negroponte implied that the network had been dismantled when he asserted in a January 11, 2007, statement to the Senate Select Committee on Intelligence that "Pakistan had been a major source of nuclear proliferation until the disruption of the A.Q. Khan network." 170 When asked about the network's current status during a July 25, 2007, Senate Foreign Relations Committee hearing, then-Under Secretary for Political Affairs Nicholas Burns replied that

I cannot assert that no part of that network exists, but it's my understanding based on our conversations with the Pakistanis that the network has been fundamentally dismantled. But to say that there are no elements in Pakistan, I'm not sure I could say that. ${ }^{171}$

Similarly, the London-based International Institute for Strategic Studies found in a May 2007 report that "at least some of Khan's associates appear to have escaped law enforcement attention and could ... resume their black-market business." $" 172$ The State Department imposed sanctions in 2009 on 13 individuals and three companies for their involvement in the Khan network. The sanctions were imposed under the Export-Import Bank Act, the Nuclear Proliferation Prevention Act, and Executive Orders 12938 and 13382.

A Pakistani Foreign Office spokesperson told reporters in May 2006 that the government considered the Khan investigation "closed"- a position an office spokesperson reiterated on February 6, 2009. Acting Assistant Secretary of State Vann Van Diepen described the network as "basically defunct" during a July 22, 2010, congressional hearing, adding that "we're on the lookout for sort of the next A.Q. Khan network, so to speak." ${ }^{173}$ Furthermore, a March 2012 State Department report described the network as "defunct" and the 2013 version of the same report stated that "[t]here is no indication" that the Pakistani government "has supplied nuclear weapons-related materials to other countries or non-state actors" since the Khan network was "exposed and shut down in 2004." 174

(...continued)

Diplomacy in Treacherous Times (New York: Metropolitan Books), 2011, p. 155) and the International Institute for Strategic Studies described the design as "95\% complete" (Nuclear Black Markets, 2007, p. 79). Moreover, Khan told a former member of his network that he had "supplied the Libyans with plans for a non-working nuclear device" (Extract from the Statement of Sayed Abu Tahir Bin Bukhary, June 7, 2006, Annexure L in Plea and Sentence Agreement, State vs. Geiges, Wisser, and Krisch Engineering, September 2007). According to former SPD official Feroz Khan, "the bomb design exposed in Libya was not the one Pakistani scientists worked on and eventually tested" (Khan, 2012, p. 189).

In addition to the documents supplied to Tripoli, members of the network also had computer files containing "drawings for the components of two smaller, more advanced nuclear weapons" (David Albright, Peddling Peril: How the Secret Nuclear Trade Arms America's Enemies, The Institute for Science and International Security, 2010. p.151). However, according to former IAEA official Olli Heinonen, these "detailed designs" were not "complete sets" of weapons design information. Heinonen suggested that other members of the network could have possessed more complete nuclear weapons designs (interview with CRS analyst, August 4, 2011).

${ }^{170}$ Unclassified Statement for the Record Annual Threat Assessment, Senate Select Committee on Intelligence, January 11, 2007.

171 “Pakistan's Future: Building Democracy, or Fueling Extremism?" Senate Committee on Foreign Relations, July 25, 2007.

${ }^{172}$ Nuclear Black Markets, 2007, p. 159.

173 "Transshipment And Diversion: Are U.S. Trading Partners Doing Enough To Prevent The Spread Of Dangerous Technologies?" Hearing of the Terrorism, Nonproliferation and Trade Subcommittee of the House Foreign Affairs Committee, July 22, 2010.

${ }^{174}$ Report to Congress: Update on Progress toward Regional Nuclear Nonproliferation in South Asia, submitted March (continued...) 
Asked during the 2007 hearing about Pakistan's cooperation in investigating the network, Burns acknowledged that the United States had not had "personal, consistent access" to Khan, but added that he did not "have all the details of everything we've done." Sources report that Islamabad has responded to written questions from the IAEA and has been cooperative with the agency's investigation of Iran's nuclear program. ${ }^{175}$ Former IAEA official Olli Heinonen, who investigated the Khan network during his time at the agency, stated in an interview published in October 2011 that Khan "answer[ed] some of my questions in writing through secret channels." recently, then-Under Secretary of State for Arms Control and International Security Ellen Tauscher told the Senate Foreign Relations Committee in 2009 that the United States has "obtained a great deal of information about the Khan network without having direct access to A.Q. Khan." "177

\section{Interactions with Al-Qaeda}

According to reports, Al-Qaeda unsuccessfully sought nuclear weapons assistance from the Khan network ${ }^{178}$ but did receive limited help from at least one other group in Pakistan. Retired Pakistan Atomic Energy Commission scientists, long-time rivals of A. Q. Khan, and Islamic fundamentalists - Sultan Bashiruddin Mahmood and Chaudiri Abdul Majeed may have provided some help to al-Qaeda representatives. ${ }^{179}$ The assistance under the umbrella of the Umma Tameer-e Nau (UTN) humanitarian organization was reportedly related to weapons of mass destruction, but details are scarce on the extent of the transfers, and the events following the September 11, 2001, attacks on the United States may have cut off this interaction.

Mahmood and Majeed met with Osama bin Laden and Ayman al-Zawahiri in August 2001 in Afghanistan to discuss, among other topics, the necessary elements for developing a nuclear weapons infrastructure, details of nuclear bomb design, and how to construct radiological dispersal devices. ${ }^{180}$ Mahmood was a public figure well-known for his eccentric and extreme views about science and Islam, and he was demoted in 1999 to a lower rank in part because of his radicalism. Mahmood then sought early retirement and started the UTN organization. After the United States briefed the Pakistani government about this activity at the highest levels in the fall of 2001, the Pakistani authorities detained the Mahmood and Majeed for multiple rounds of questioning. Through these interrogations and searches in Afghanistan, UTN's work with al-

(...continued)

20, 2012; Report to Congress: Update on Progress toward Regional Nuclear Nonproliferation in South Asia, submitted April 3, 2013.

${ }^{175}$ Personal communication, November 9, 2007.

176 "Former IAEA Deputy Chief Voices Concern About Iran, North Korea, Pakistan,” Der Spiegel, October 2, 2011.

${ }^{177}$ Question \#54, Pre-Hearing Questions for the Record by Senator Richard Lugar Senate Foreign Relations Committee, Nomination of Ellen M. Tauscher to be Under Secretary of State for Arms Control and International Security.

${ }^{178}$ Former Director of Central Intelligence George Tenet wrote in his memoirs that the United States "received fragmentary information from an intelligence service" that in 1998 Osama bin Laden had "sent emissaries to establish contact" with the Khan network. Tenet, George and Harlow, Bill, At the Center of the Storm: My Years at the CIA, HarperCollins: New York, 2007. p. 261; Albright, Peddling Peril, 2010.

${ }^{179}$ For a detailed discussion, see Albright, 2010.

${ }^{180}$ Albright, ibid. According to a 2005 report by the Commission on the Intelligence Capabilities of the United States Regarding Weapons of Mass Destruction, al-Qaeda "had established contact with Pakistani scientists who discussed development of nuclear devices that would require hard-to-obtain materials like uranium to create a nuclear explosion. http://www.wmd.gov/report/index.html. 
Qaeda on biological weapons and rudimentary nuclear weapons technology came to light. ${ }^{181}$ The Pakistani government did not press criminal charges against Mahmood and Majeed, but put the scientists under house arrest in 2002. This extreme case raised awareness of the "insider threat" and subsequently led to changes in Pakistani personnel security policy, detailed below. Accounts raise the possibility of other groups or individuals also providing al Qaeda or other groups with nuclear expertise, but less information is publicly available. ${ }^{182}$

\section{Pakistan's Response to the Proliferation Threat}

Then-Under Secretary Burns testified in July 2007 that the Bush Administration has "told the Pakistani government that it is its responsibility ... to make sure" that neither the Khan network nor a "similar organization" resurfaces in the country. Since the revelations about the network, Pakistan appears to have increased its efforts to prevent nuclear proliferation. Ambassador Olson argued during a December 16, 2015, House Foreign Affairs Committee hearing that Pakistan has "made considerable progress" in its nonproliferation efforts. It is worth noting that, because Khan conducted his proliferation activities as a government official, they do not necessarily indicate a failure of Islamabad's export controls.

Pakistani officials argue that Islamabad has taken a number of steps to prevent further proliferation of nuclear-related technologies and materials. ${ }^{183}$ For example, Islamabad adopted in September 2004 new national export controls legislation which includes a requirement that the government issue control lists for "goods, technologies, material, and equipment which may contribute to designing, development, stockpiling, [and] use" of nuclear weapons and related delivery systems. According to a February 2008 presentation by the Director of Pakistan's Strategic Export Controls Division (SECDIV), ${ }^{184}$ the lists, which were issued in October 2005, include items controlled by multilateral export control regimes, such as the Nuclear Suppliers Group, the Australia Group, and the Missile Technology Control Regime. ${ }^{185}$ The government issued revised control lists in 2011 and 2015. ${ }^{186}$ According to a 2013 State Department report, the 2011 revisions contained "gaps" which must be closed before the lists are "fully harmonized with the multilateral [export control regimes." 187 Whether the 2015 revisions addressed these gaps is unclear.

\footnotetext{
${ }^{181}$ Albright, ibid. Tenet, ibid.

${ }^{182}$ Albright, ibid.

${ }^{183}$ Details of Pakistan's nuclear-related legislation can be found in the country's reports to the UN 1540 Committee. Both can be found at http://daccessdds.un.org/doc/UNDOC/GEN/N04/597/46/PDF/N0459746.pdf?OpenElement.

${ }^{184}$ Presentation given to Partnership for Global Security Workshop, "Meeting the Nuclear Security Challenge in Pakistan," February 21-22, 2008. http://www.partnershipforglobalsecurity.org/documents/zafar_export.pdf.

185 The Nuclear Suppliers Group is a multilateral, voluntary group of nuclear supplier states which have agreed to coordinate their exports of civilian nuclear technology and materials in order to prevent importers from using them to produce nuclear weapons. The Australia Group is a voluntary, informal, export-control arrangement through which participating countries coordinate their national export controls to limit the supply of chemicals and biological agents, as well as related equipment, technologies, and knowledge, to countries and nonstate entities suspected of pursuing chemical or biological weapons capabilities. The Missile Technology Control Regime is an informal, voluntary arrangement in which participants agree to adhere to common export policy guidelines applied to an "annex" that lists items related to the proliferation of ballistic and cruise missiles, rockets, and unmanned air vehicles capable of delivering weapons of mass destruction.

${ }^{186}$ Communication of 30 September 2015 from the Permanent Mission of Pakistan to the Agency Concerning the Export Control Policies of the Government of Pakistan and a Statutory Regulatory Order, International Atomic Energy Agency, INFCIRC/890, November 9, 2015.

${ }^{187}$ Report To Congress, April 3, 2013.
} 
The export controls legislation also includes a catch-all clause, which requires exporters to notify the government if they are aware or suspect that goods or technology are intended by the end-user for use in nuclear or biological weapons, or missiles capable of delivering such weapons. ${ }^{188}$ The legislation includes several other important elements, such as end-use and end-user certification requirements and new penalties for violators. Since its adoption, Pakistan has established the SECDIV and an associated Oversight Board. The SECDIV is responsible for formulating rules and regulations for implementing the legislation. The board is comprised of officials from multiple agencies and is headed by Pakistan's Foreign Secretary.

Islamabad says that it has also taken several other steps to improve its nuclear security. For example, the government announced in June 2007 that it is "implementing a National Security Action Plan with the [IAEA's] assistance." That same month, Pakistan also joined the U.S.- and Russian-led Global Initiative to Combat Nuclear Terrorism. As noted above, the December 2007 National Command Authority Ordinance also includes measures to prevent the spread of nuclearrelated materials and expertise.

Pakistani officials participating in an April 2007 Partnership for Global Security workshop argued that Islamabad has improved the reliability of its nuclear personnel by, for example, making security clearance procedures more stringent. However, the officials also acknowledged that Islamabad still needed to do more to control its nuclear expertise. ${ }^{189}$ Similarly, then-Chairman of the Joint Chiefs of Staff Mullen stated on May 14, 2009, that the country's personnel reliability system must "continue to improve." Some reports about the early January 2011 shooting of Salmaan Taseer, the governor of Punjab province, have raised questions about Pakistan's ability to vet security personnel properly. ${ }^{190}$

The United States has provided export control assistance to Pakistan. Burns described several such efforts in his July 2007 testimony. ${ }^{191}$ And according to an October 2007 U.S. Government Accountability Office report, Islamabad was during FY2003-FY2006 the second-largest recipient of bilateral U.S. assistance designed to improve target countries' export controls. Pakistan received such assistance from the Departments of State, Energy, and Homeland Security. ${ }^{192}$ More recently, the United States has "provided feedback to Pakistan on improving its strategic trade controls," according to the 2013 State Department report. ${ }^{193}$

\footnotetext{
${ }^{188}$ The Chemical Weapons Convention Implementation Ordinance of 2000 regulates the import and export of chemicals in accordance with the convention.

${ }^{189}$ Building Confidence in Pakistan's Nuclear Security: Workshop Synopsis. April 30, 2007.

${ }^{190}$ Asif Shahzad, "Pakistani Governor Killed by own Bodyguard," Associated Press, January 4, 2011; Salman Masood and Carlotta Gall, "Crisis Grows in Pakistan with Killing of Governor; Government Shaken amid Fears Islamists have Infiltrated Security Forces," The International Herald Tribune, January 6, 2011; Asif Shahzad and Sebastian Abbot, "Shadow over Pakistan Security Grows," Associated Press, January 12, 2011.

${ }^{191}$ Burns mentioned Pakistan's participation in the Container Security Initiative and the Secure Freight Initiative. Under these programs, "the United States and Pakistan worked together to install screening and radiation detection equipment to scan U.S.-bound cargo." He also stated that the Department of Energy "is working with Pakistan on radiation source security and is in the process of finalizing an agreement to install radiation detection equipment at Pakistani ports and border crossings."

${ }^{192}$ GAO Report, Nonproliferation: U.S. Efforts to Combat Nuclear Networks Need Better Data on Proliferation Risks and Program Results, October 31, 2007.

${ }^{193}$ Report To Congress, April 3, 2013.
} 


\section{Pakistan's Civil Nuclear Program}

Pakistan sees nuclear power as a key component of its economic development and energy security. The country obtains slightly less than 5\% of its power from nuclear energy, or $400 \mathrm{MWe}$ and electricity consumption in Pakistan is increasing. Islamabad plans to increase nuclear energy production to 8,800 MWe by 2030 and 40,000 MWe by $2050 .{ }^{194}$ The Pakistan Atomic Energy Commission is in charge of nuclear $\mathrm{R} \& \mathrm{D}$, and all research and power reactors.

Pakistan operates three civilian power reactors under International Atomic Energy Agency (IAEA) safeguards ${ }^{195}$ at two sites: a Canadian-supplied 100 MWe heavy-water-moderated reactor in Karachi (Karachi Nuclear Power Plant 1 (KANUPP)), which began operating in 1971, and two Chinese-built 325 MWe pressurized water reactors (PWRs) at the Chasma site. Chasma-1 started operation in 2000, and Chasma-2 in 2011. Two additional reactors are being built at KANUPP by the China National Nuclear Corporation (CNNC). There are plans for a fourth reactor at KANUPP; the first reactor will be shut down. At the Chasma site, CNNC is constructing two additional reactors. Furthermore, China and Pakistan have discussed Chinese construction of "three additional nuclear reactors" to be built at Muzaffargarh in central Pakistan. ${ }^{196}$

U.S. officials and other NSG members have said that the Chasma-3 and -4 sales by China, are inconsistent with current Nuclear Suppliers Group (NSG) guidelines. ${ }^{197}$ Contracts for Chasma-1 and -2 were concluded before China joined the NSG in 2004. At that time, other NSG members agreed "to grandfather construction of plants in Pakistan which China had initiated," Assistant Secretary of State Thomas Countryman said during a May 12, 2015, Senate Foreign Relations Committee hearing. In 2008, China and Pakistan agreed to the Chasma-3 and -4 construction "in response to the U.S.-India Peaceful Nuclear Cooperation Agreement," according to a 2015 Nuclear Proliferation Assessment Statement submitted by the Obama administration to Congress. ${ }^{198}$ China argues that the contracts for Chasma -3 and -4 are grandfathered, but Countryman stated that the NSG did not agree to grandfather any additional reactors. As noted, the NSG changed its guidelines in 2008 to allow nuclear trade with India, but the group does not allow trade with Pakistan. At present, China is apparently the only country planning to sell nuclear power reactors to Pakistan.

Pakistan also operates two research reactors-Pakistan Research Reactor 1, which went critical in $1965,{ }^{199}$ and Pakistan Research Reactor 2, which went critical in 1989. ${ }^{200}$ Pakistan Research Reactor 1, which was originally supplied by a U.S. firm, was converted from using highlyenriched uranium (HEU) to low-enriched uranium fuel in $1992 .{ }^{201} \mathrm{~A}$ "small amount" of the HEU fuel remains in Pakistan. ${ }^{202}$

\footnotetext{
${ }^{194}$ Pakistan Nuclear Regulatory Authority Annual Report 2014; Statement by the Leader of the Pakistan Delegation, $59^{\text {th }}$ IAEA General Conference, 14-18 September, 2015.

${ }^{195}$ Unlike most International Atomic Energy Agency safeguards agreements, Pakistan's agreements only cover certain nuclear facilities in the country. Islamabad's nuclear weapons program is not safeguarded. "Pakistan is committed to keep all its future civil nuclear facilities under IAEA safeguards" ("Pakistan \& The NSG," non-paper from the Embassy of Pakistan circulated on June 3, 2015).

${ }^{196}$ Nuclear Proliferation Assessment Statement, April 21, 2015.

197 See CRS Report RL33192.

198 Nuclear Proliferation Assessment Statement, April 21, 2015.

${ }^{199}$ Research Reactor Details - PARR-1. http://www.iaea.org/worldatom/rrdb/.

${ }^{200}$ Research Reactor Details - PARR-2. http://www.iaea.org/worldatom/rrdb/.

${ }^{201}$ I.H. Qureshi, "Recollections from the Early Days of the PAEC," The Nucleus, 42 (1-2), 2005, pp. 7-11. Research (continued...)
} 


\section{Issues for Congress}

Legislation to authorize various forms of U.S. assistance to Pakistan contains provisions related to Islamabad's nuclear weapons program. S. 1707, the Enhanced Partnership with Pakistan Act of 2009, which became law (P.L. 111-73) on October 15, 2009, authorizes various forms of U.S. assistance to Pakistan, including strengthening democratic institutions and law enforcement, as well as supporting economic development, education, human rights, and heath care. P.L. 111-73 requires the President to certify that Pakistan is "continuing to cooperate with the United States in efforts to dismantle supplier networks relating to the acquisition of nuclear weapons-related materials, such as providing relevant information from or direct access to Pakistani nationals associated with such networks." It also requires a Semi-Annual Monitoring Report that is to include a detailed description of Pakistan's nuclear non-proliferation efforts and an assessment of whether assistance has

directly or indirectly aided the expansion of Pakistan's nuclear weapons program, whether by the diversion of United States assistance or the reallocation of Pakistan's financial resources that would otherwise be spent for programs and activities unrelated to its nuclear weapons program.

In response to concerns expressed in Pakistan over the intent of the bill, a "Joint Explanatory Statement" was submitted for the Congressional Record by then-Senate Foreign Relations Committee Chairman John Kerry and then-House Foreign Affairs Committee Chairman Howard Berman. The statement emphasizes that "the legislation does not seek in any way to compromise Pakistan's sovereignty, impinge on Pakistan's national security interests, or micromanage any aspect of Pakistani military or civilian operations." Regarding reporting requirements on nuclear nonproliferation cooperation, the statement says:

The many requirements of this report are intended as a way for Congress to assess how effectively U.S. funds are being spent, shortfalls in U.S. resources that hinder the use of such funds, and steps the Government of Pakistan has taken to advance our mutual interests in countering extremism and nuclear proliferation and strengthening democratic institutions.

There is no intent to, and nothing in this Act in any way suggests that there should be, any U.S. role in micromanaging internal Pakistani affairs, including the promotion of Pakistani military officers or the internal operations of the Pakistani military. ${ }^{203}$

Sections 9017(a) and 7044(d)(1) of the Consolidated Appropriations Act, 2016 (P.L. 114-113) require the Secretaries of State and Defense to certify that Pakistan is "preventing the proliferation of nuclear-related material and expertise" in order for Pakistan to receive certain U.S. funds. These sections contain waiver provisions.

It is worth noting that Pakistani officials have expressed interest in concluding a nuclear cooperation agreement with the United States, which would require congressional approval. Then-Prime Minister Gilani told a visiting congressional delegation in June 2011 that such cooperation "would help build a positive image of the U.S. in the country." ${ }^{204}$ More recently,

\footnotetext{
(...continued)

Reactor Details - PARR-1.

${ }^{202}$ Matthew Bunn, Securing the Bomb 2010: Securing All Nuclear Materials in Four Years, (Cambridge, MA., and Washington, DC: Project on Managing the Atom, Harvard University, and Nuclear Threat Initiative), April 2010, p. 28.

${ }^{203}$ See Congressional Record S10429-S10431.

${ }^{204}$ Press Information Department, "United States Congressional Delegation calls on Prime Minister Gilani," Pakistan (continued...)
} 
however, Pakistan appears to have emphasized its desire for membership in the NSG. ${ }^{205}$ Islamabad has argued that it is "eminently qualified" for NSG membership, citing the country's potential as an exporter of civil nuclear goods and what Islamabad says are effective export controls, a good record regarding nuclear safety and security, and adherence to its IAEA safeguards agreements. ${ }^{206}$ Pakistan has also asserted that continued exclusion of the country from the NSG "would adversely affect regional peace, security and stability," as well as "undermine the global non-proliferation regime." ${ }^{207}$ According to U.S. law, the United States could apparently advocate for Pakistan's NSG membership without congressional approval. Ambassador Olson testified on December 16, 2015, that the Obama Administration is "not negotiating ... civil nuclear cooperation agreement with... Pakistan." However, press reports indicate that the United States is considering supporting Islamabad's NSG membership in exchange for Pakistani actions to reduce perceived dangers associated with the country's nuclear weapons program. ${ }^{208}$

\section{Author Contact Information}

Paul K. Kerr

Analyst in Nonproliferation

pkerr@crs.loc.gov, 7-8693
Mary Beth Nikitin

Specialist in Nonproliferation

mnikitin@crs.loc.gov, 7-7745

(...continued)

Official News, June 7, 2011.

205 “Pakistan Seeks Nuclear Deal on Par with India," Dawn, November 8, 2005.

${ }^{206}$ Ibid; "Pakistan \& The NSG."

207 "Pakistan \& The NSG."

${ }^{208}$ Daniel Horner, "Pakistan, U.S. Said to Be Talking on NSG," Arms Control Today, November 2015; David E. Sanger, "U.S. Exploring Deal to Limit Pakistan's Nuclear Arsenal," New York Times, October 15, 2015; Douglas Busvine, "Nuclear Club Eyes Indian Inclusion, but Risks Pakistan's Ire,” Reuters, November 24, 2015. 